\title{
Microbial Tyrosinases: Promising Enzymes for Pharmaceutical, Food Bioprocessing, and Environmental Industry
}

\author{
Kamal Uddin Zaidi, ${ }^{1,2}$ Ayesha S. Ali, ${ }^{2}$ Sharique A. Ali, ${ }^{2}$ and Ishrat Naaz \\ ${ }^{1}$ Molecular Biotechnology Laboratory, Centre for Scientific Research \& Development, People’s University, Bhanpur, \\ Bhopal 462010, India \\ ${ }^{2}$ Department of Biotechnology, Saifia College of Science, Bhopal 462001, India
}

Correspondence should be addressed to Ayesha S. Ali; drayeshariqali@yahoo.com

Received 3 February 2014; Accepted 31 March 2014; Published 6 May 2014

Academic Editor: Joel H. Weiner

\begin{abstract}
Copyright ( 2014 Kamal Uddin Zaidi et al. This is an open access article distributed under the Creative Commons Attribution License, which permits unrestricted use, distribution, and reproduction in any medium, provided the original work is properly cited.

Tyrosinase is a natural enzyme and is often purified to only a low degree and it is involved in a variety of functions which mainly catalyse the $o$-hydroxylation of monophenols into their corresponding $o$-diphenols and the oxidation of $o$-diphenols to $o$-quinones using molecular oxygen, which then polymerizes to form brown or black pigments. The synthesis of $o$-diphenols is a potentially valuable catalytic ability and thus tyrosinase has attracted a lot of attention with respect to industrial applications. In environmental technology it is used for the detoxification of phenol-containing wastewaters and contaminated soils, as biosensors for phenol monitoring, and for the production of L-DOPA in pharmaceutical industries, and is also used in cosmetic and food industries as important catalytic enzyme. Melanin pigment synthesized by tyrosinase has found applications for protection against radiation cation exchangers, drug carriers, antioxidants, antiviral agents, or immunogen. The recombinant $V$. spinosum tryosinase protein can be used to produce tailor-made melanin and other polyphenolic materials using various phenols and catechols as starting materials. This review compiles the recent data on biochemical and molecular properties of microbial tyrosinases, underlining their importance in the industrial use of these enzymes. After that, their most promising applications in pharmaceutical, food processing, and environmental fields are presented.
\end{abstract}

\section{Introduction}

Tyrosinase (EC 1.14.18.1) is a copper-containing monooxygenase catalyzing the $o$-hydroxylation of monophenols to the corresponding catechols (monophenolase or cresolase activity) and the oxidation of monophenols to the corresponding $o$-quinones (diphenolase or catecholase activity). It is involved in the biosynthesis of melanin and catalyses the ortho-hydroxylation of tyrosine (monophenol) to 3,4dihydroxyphenylalanine or DOPA (o-diphenol) and the oxidation of DOPA to dopaquinone (o-quinone). This o-quinone can then be transformed into melanin pigments through a series of enzymatic and nonenzymatic reaction $[1,2]$. Not only the physiological substrates tyrosine and L-DOPA but also various other phenols and diphenols are converted by tyrosinase to the corresponding diphenols and quinones, respectively. Thus, in general, tyrosinase catalyses both the ortho-hydroxylation of monophenols (cresolase or monophenolase activity) and the two-electron oxidation of $o$-diphenols to $o$-quinones (catecholase or diphenolase activity). These reactions take place under concomitant reduction of dioxygen to water. The mechanism by which an oxygen atom is transferred to the phenol substrate is proposed to begin with either a $\mu-\eta^{2}: \eta^{2}$-peroxodicopper (II) intermediate or a bis$\mu$-oxodicopper (III) intermediate. These intermediates have characteristic resonance Raman spectra. Synthetic studies provide models of both complexes and evidence for rapid equilibrium between the two forms [3]. The monophenol hydroxylase and diphenoloxidase activities of tyrosinases are the basis for many industrial biotechnological applications like in environmental technology for the detoxification of phenol-containing waste waters and contaminated soils as 
a construction of a biosensor for the detaction of phenolic compound [4] and in pharmaceutical industries for the production of $o$-diphenols (e.g., L-DOPA, dopamine for the treatment of Parkinson's disease) and also have been tested as a marker in melanoma patients [5] and as a target for the activation of prodrugs [6] in food industries for modification of food proteins via crosslinking affects [7]. Synthetic melanin is also used for protection against radiation (UV, X-ray, and gamma ray), cation exchangers, drug carriers, antioxidants, antiviral agents, or immunogen. There is considerable information representing the great potential of this enzyme for food, medicine, and agricultural industries as well as for analytical and environmental purposes [8-10].

The best-characterized tyrosinases are derived from Streptomyces glaucescens and the fungi Neurospora crassa and Agaricus bisporus. In fungi and vertebrates, tyrosinase catalyzes the initial step in the formation of the pigment melanin form tyrosine. In plants, the physiological substrates are variety of phenolics and tyrosinase oxidizes them in the browning pathway observed when tissues are injured. The enzyme extracted from the champignon mushroom Agaricus bisporus is highly homologous with the mammalian ones, and this renders it well suited as a model for studies on melanogenesis. In fact, almost all studies on tyrosinase inhibition conducted so far have used mushroom tyrosinase because the enzyme is commercially available [11]. It was investigated by Molloy et al. [12] recently that bacterial tyrosinase from Ralstonia solanacearum can be modified through engineering which in turn is used for the improved catalytic efficiency towards D-tyrosine using random and site directed mutagenesis. Mushrooms are considered a cheap source of the tyrosinase. Mushroom tyrosinase from Agaricus bisporus is a tetramer of about $120 \mathrm{KDa}$ with monomeric isoforms with molecular masses of $30 \mathrm{KDa}$. Furthermore, microbial tyrosinase (mushroom tyrosinase) like mammalian tyrosinase has a tetrameric structure and can be used for clinical purposes [13].

All these features have made microbial tyrosinases a suitable tool for today's pharmaceutical, food bioprocessing, and environmental technology. For different purposes, we review the potential applications of microbial tyrosinases and evaluate the state of knowledge about their isolation production, purification, sources, biochemical properties, and applications. We conclude that much more research is required in these areas as microbial tyrosinases can fulfill their industrial potential. Whereas tyrosinases are widely distributed in mushroom, plants, invertebrates, and mammals, much of the modern significance in the development of pharmaceutical, food bioprocessing, and environmental applications has focused on the use of microbial tyrosinases. This paper presents recent advances in tyrosinases from microbial origin with emphasis on their biochemical properties and discusses their current and potential applications.

\section{Sources of Tyrosinase}

Tyrosinase activities are widely distributed in all domains of life from microorganisms to mammals. Tyrosinases have been purified and their properties and functions have been extensively studied. They are found in whole cells, tissues from mushrooms, fruits, and vegetables and are mainly involved in the biosynthesis of melanins and other polyphenolic compounds.

2.1. Fungus as a Source of Tyrosinase. Different fungi have been investigated for the isolation of tyrosinase which has been obtained from Agaricus bisporus [14], Neurospora crassa [15, 16], Amanita muscaria [17], Lentinula edodes [18], Aspergillus oryzae [19], Portabella mushrooms, Pycnoporus sanguineus [20], and Lentinula boryana [21].

2.2. Bacteria as a Source of Tyrosinase. Streptomyces tyrosinases are the most thoroughly characterized enzymes of bacterial origin $[22,23]$. Bacterial tyrosinase is involved in the melanin production and is normally extracellular in origin. The enzyme has been reported in other species such as Rhizobium, Symbiobacterium thermophilum, Pseudomonas maltophilia, Sinorhizobium meliloti, Marinomonas mediterranea, Thermomicrobium roseum, Bacillus thuringiensis, Pseudomonas putida [24-26], Streptomyces castaneoglobisporus, Ralstonia solanacearum, and Verrucomicrobium spinosum [27].

2.3. Plants as a Source of Tyrosinase. Tyrosinase from various fruits and vegetables has been studied and the enzyme has been extracted from Monastrell grape (Janovitz-Klapp et al. 1989), apple [28], sunflower seed [29], and Solanum melongena [30]. In plants, tyrosinase is localized in the chloroplasts of healthy plant tissues, whereas its substrates are contained in the vacuole. Portulaca grandiflora (Portulacaceae) is a potent source of tyrosinase [31-33]. It generally causes undesired enzymatic browning of farm products which subsequently leads to a significant decrease in the nutritional and market values.

\section{Structural Properties of Tyrosinase}

Tyrosinase is diverse in terms of its structural properties, tissue distribution, and cellular location as no common tyrosinase protein structure occurs across all species [34, 35]. The enzyme frequently differs to its primary structure, size, glycosylation pattern, and activation characteristics. However, all tyrosinases have a common binuclear type III copper centre (T3Cu), of two copper atoms, each coordinated by three histidine residues, within their active site. The copper pair present in their active site binds to atmospheric oxygen so as to catalyze two different kinds of enzymatic reactions (I) ortho-hydroxylation of monophenols and (II) oxidation of $o$-diphenols to $o$-quinones, similar to the coordination mode found in hemocyanins. In the crystal structures of these enzymes, six histidine residues, which are provided by a fourhelix bundle in the copper-binding domain to the two copper ions (three histidine imidazoles for each copper ion, CuA and $\mathrm{CuB}$ ), in the active site (Figures 1(a) and 1(b)). Tyrosinases and catechol oxidases are collectively termed polyphenol oxidases due to their similar activity with catechol oxidase. Mushroom tyrosinase is a tetrameric glycoprotein copper 


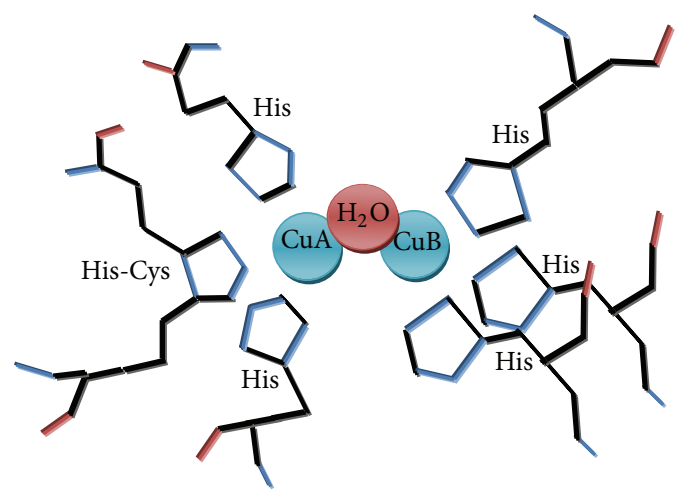

(a)

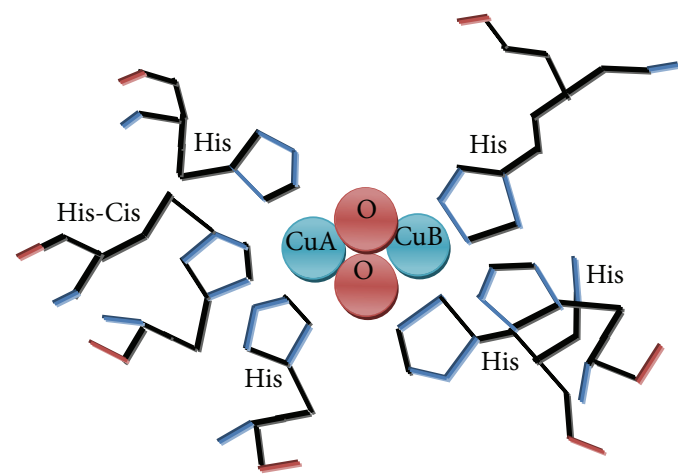

(b)

FIGURE 1: Structure of tyrosinase.

containing metalloenzyme with a molecular weight of $128 \pm$ $6.4 \mathrm{kD}$ and a subunit molecular weight of $32 \mathrm{kD}$ [36]. Four tyrosinase genes of the common button mushroom, Agaricus bisporus, have been investigated to date. Wichers and coworkers have found two genes encoding two $64 \mathrm{kDa}$ tyrosinases; ppol (Genebank accession number X85113) and ppo2 (AJ223816) were studied by Wichers et al, whereas the other two genes, which encode a 66 and $68 \mathrm{kDa}$ tyrosinase ppo3 (GQ354801) and ppo4 (GQ354802), were recently reported by Wu et al. [37]. Unlike the fungal tyrosinase, human tyrosinase is a membrane-bound glycoprotein [38]. Experimental data suggests tyrosinase to be a monomeric protein with more than one isoform $[13,39,40]$. Similarly, bacterial tyrosinases from Streptomyces species are nonmodified monomeric proteins with a relatively low molecular mass of $30 \mathrm{kDa}$. These enzymes are secreted to the surrounding medium and are involved in extracellular melanin production. Tyrosinase exists in three forms in the catalytic cycle (met, oxy, and deoxy) with different binuclear copper structure of the active site which are involved in the biosynthesis of melanin [15, 16, 41, 42]. Microbial tyrosinases have been divided into five types according to the organization of domain and the possible requirement of a caddie protein for enzyme activity [43]. The necessity of a secondary helper protein (caddie protein) for secretion, correct folding, assembly of the copper atoms, and activity of the enzyme is common to tyrosinases of type I, for example, the enzyme from $S$. casstaneoglobisporus and $S$. antibioticus. Type II tyrosinases are small monomeric enzymes containing only the catalytic domain, which do not require additional helper proteins and are possibly secreted. An example is the tyrosinase from B. Megaterium [44]. Type III tyrosinases are represented by the enzyme from Verrucomicrobium spinosum. Like the fungal tyrosinases it carries a C-terminal domain whose removal led to about 100fold higher activity [45]. This supports the theory that the role of the C-terminal extension in plant and fungal tyrosinases is to keep the enzyme in an inactive form inside the cell $[46,47]$. Among the smallest bacterial tyrosinases reported (type IV) are the ones produced by Streptomyces ingrifaciens $(18 \mathrm{kDa})$ and Bacillus thuringiensis (14 kDa) [24].

\section{Biochemical Features of Microbial Tyrosinase}

In this section we provide a brief outline of the biochemical characteristics of the most studied microbial tyrosinase; several scientists all over the world are working on the biochemical properties of the enzyme tyrosinase as depicted in Table 1. Tyrosinase has broad substrate specificity where the enzyme has a higher affinity for the L-isomers of the substrates than for the corresponding D-isomers [48]. Tyrosinase derived from Streptomyces glaucescens, Neurospora crassa, and Agaricus bisporus is best characterized. Tyrosinase catalyzes the formation of the pigment melanin from tyrosine whereas, in plants, phenolics act as a physiological substrate. Tyrosinases exist in immature, mature latent, and active isoforms [49, 50]. Kinetic studies of the steady state of the pathway show the lower catalytic efficiency of tyrosinase on monophenols than on $o$-diphenols [51-53]. Kinetic studies also show the activation of tyrosinase and the decrease in lag time due to the presence of reducing agents (cofactors, especially $o$-diphenol derivatives such as L-DOPA and (+)-catechin). Mammalian tyrosinase is found specially in melanocytes, which are highly specialized cells located in the skin, hair bulbs, and eyes which produce pigments. Mammalian tyrosinase goes through an extensive process of posttranslational modification which occurs in Golgi complex [54].

\section{Isolation of Tyrosinases}

Tyrosinases have been isolated from plants, fungi, actinomycetes, and bacteria. A homology search of the genome database of the filamentous fungus Trichoderma reesei identified a new $T$. reese $i$ tyrosinase gene tyr 2 , encoding a protein with a putative signal sequence. The gene was over expressed in the native host under the strong cbh1 promoter, and the tyrosinase enzyme was secreted into the culture supernatant [63]. Isolation of tyrosinase requires ample of process, as it could not be isolated in sufficient quantities and purities for detailed structural studies and thus isolation of tyrosinase from bacteria is simple. For example, the Streptomyces 
TABLE 1: Biochemical properties of tyrosinase.

\begin{tabular}{|c|c|c|c|c|c|c|c|}
\hline Sources & $\begin{array}{c}\mathrm{MW} \\
\mathrm{kDa} / \mathrm{Da}\end{array}$ & Optimum temperature & Optimum pH & $\mathrm{pI}$ & $\mathrm{kM}(\mathrm{mM})$ & Specific activity & References \\
\hline Aeromonas media & 58000 & $50^{\circ} \mathrm{C}$ & 8.0 & 4.9 & 0.64 & $34 \mu \mathrm{mol} / \mathrm{min} / \mathrm{mg}$ & {$[55]$} \\
\hline Beta vulgaris & 41000 & $25^{\circ} \mathrm{C}$ & 6.0 & NR & 0.067 & NR & {$[56]$} \\
\hline Lentinula boryana & $20,27,47$ & $50^{\circ} \mathrm{C}$ & 6.0 & $\mathrm{NR}$ & 1.9 (L-DOPA) & NR & {$[14]$} \\
\hline Neurospora crassa & 46 & NR & 5.0 & $\mathrm{NR}$ & 0.18 & $540 \mu \mathrm{mol} / \mathrm{min} / \mathrm{mg}$ & {$[9]$} \\
\hline Agaricus bisporus & 112800 & $25^{\circ} \mathrm{C}$ & 7.0 & 4.75 & 0.36 (L-tyrosine) & $8300 \mu \mathrm{mol} / \mathrm{min} / \mathrm{mg}$ & [57] \\
\hline Lentinula edodes & 70,105 & NR & 6.5 & 4.3 & 0.85 (L-DOPA) & NR & [11] \\
\hline Aspergillus oryzae & 67 & $5.0-6.0$ & NR & NR & NR & NR & [58] \\
\hline Pycnoporus sanguineus & 45000 & $25^{\circ} \mathrm{C}$ & 6.5 & 4.55 & 0.9 (L-DOPA) & $3.2 \mu \mathrm{mol} / \mathrm{min} / \mathrm{mg}$ & {$[13]$} \\
\hline Trichoderma reesei & 43.2 & $30^{\circ} \mathrm{C}$ & 9.0 & 9.5 & 7.5 (L-DOPA) & NR & {$[47]$} \\
\hline Streptomyces glaucescens & 3.09 & NR & NR & $\mathrm{NR}$ & 0.41 (L-tyrosine) & & {$[59]$} \\
\hline Aspergillus nidulans & 50.48 & NR & 7.0 & NR & NR & NR & {$[60]$} \\
\hline Bacillus megaterium & $\begin{array}{l}31000 \\
35000\end{array}$ & $50^{\circ} \mathrm{C}$ & 7.0 & NR & $\begin{array}{c}0.075 \text { (L-tyrosine) } \\
0.35 \text { (L-DOPA) }\end{array}$ & NR & {$[41]$} \\
\hline Bacillus thuringiensis & NR & $75^{\circ} \mathrm{C}$ & 9.0 & NR & $\begin{array}{c}0.563 \text { (L-tyrosine) } \\
0.768 \text { (L-DOPA) }\end{array}$ & NR & {$[61]$} \\
\hline Streptomyces sp. & 32000 & $35^{\circ} \mathrm{C}$ & 7.0 & NR & $\begin{array}{c}1.25 \text { (L-tyrosine) } \\
4.14 \text { (L-DOPA) }\end{array}$ & $130 \mu \mathrm{mol} / \mathrm{min} / \mathrm{mg}$ & {$[62]$} \\
\hline Pseudomonas putida & $\begin{array}{l}36000 \\
39000\end{array}$ & $30^{\circ} \mathrm{C}$ & 7.0 & NR & $\begin{array}{c}0.23(\mathrm{~L}-\text { tyrosine}) \\
0.33(\mathrm{~L}-\mathrm{DOPA})\end{array}$ & $0.375 \mu \mathrm{mol} / \mathrm{min} / \mathrm{mg}$ & {$[20]$} \\
\hline
\end{tabular}

NR: not reported; DOPA: dihydroxyphenylalanine.

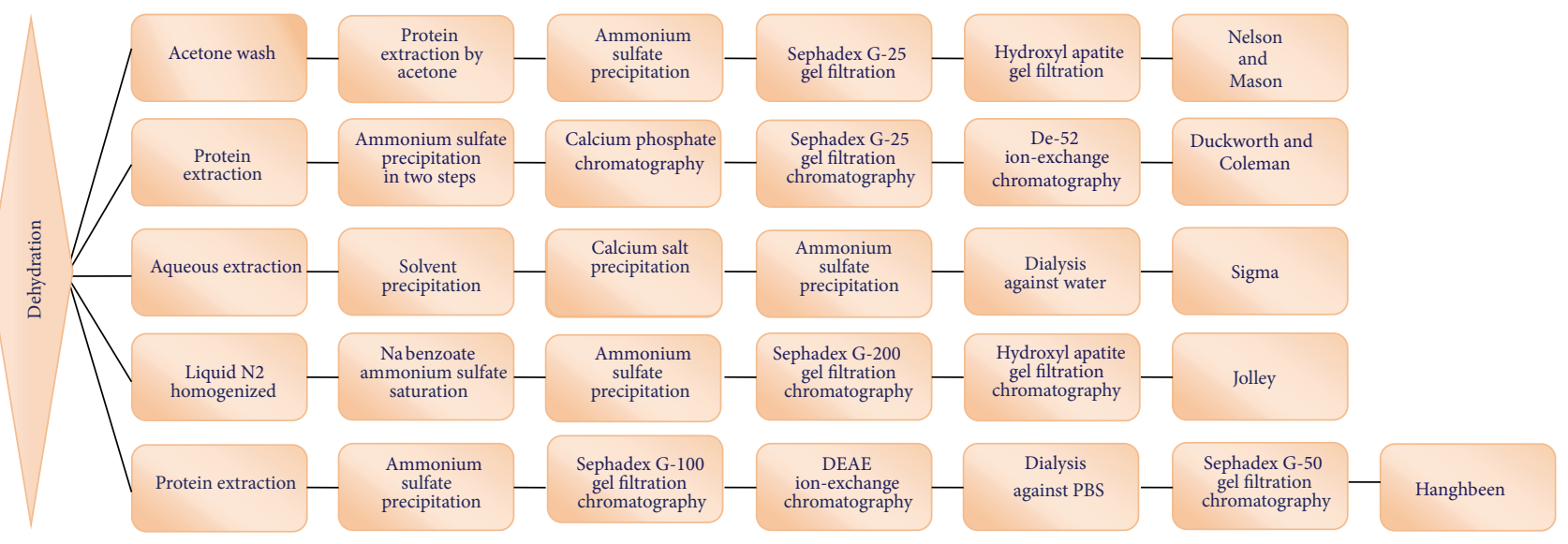

FIGURE 2: Purification scheme of tyrosinase.

tyrosinases are nonmodified monomeric protein with a low molecular mass of $30 \mathrm{kDa}$ and are secreted to the surrounding medium, where they are involved in extracellular melanin production. However, the relative activities, optimum $\mathrm{pH}$ of activity, and molecular weight of these enzymes show considerable variations. Microbial tyrosinase is either produced by submerged culture or by solid-state fermentation. Quantitative assays are a powerful tool used for screening fungi for enzyme production as they are helpful in screening large number of fungal isolates and thus provide an insight into the conditions necessary to stimulate production in submerged culture. Halaouli et al. [20] studied the production of intracellular tyrosinases from various strains of Pycnoporus cinnabarinus and Pycnoporus sanguineus. Functionally expressed a tyrosinase gene from Streptomyces antibioticus in Escherichia coli under the control of an inducible bacteriophage T7 promoter. These cells produced melanin pigments on agar plates and in liquid culture when supplemented with copper and tyrosine [23].

\section{Purification of Tyrosinase}

Tyrosinases are natural enzymes and are often purified to only a low degree. Different methods have been used for the purification of microbial tyrosinases as depicted in Figure 2. The culture filtrate dehydrated with acetone or ammonium sulfate and calcium salt is added to precipitate the enzyme and other proteins [17]. The concentration of ammonium 
sulfate also plays an important role in the precipitation of the enzyme as studies have shown variation in concentration of ammonium sulphate varying from 35\% to $70 \%$ saturated solution subsequently at two steps [64], 25-70\% [30]. Although there are numerous methods for purifying tyrosinases from different sources, few methods are cited for its production especially from various species of mushroom $[58,65,66]$. For the purification of microbial tyrosinases various columns containing hydroxylapatite [67], DEAEcellulose [68], or size exclusion gel [69] have been performed.

\section{Medicinal Application of Tyrosinases}

Tyrosinases are omnipresent in nature and are considered one of the fundamental enzymes involved in several biological functions and defense mechanism (especially in melanogenesis). Tyrosine-related melanogenesis is responsible for pigmentation of hair, skin, and eye in mammals, as pigmentation is a pivotal part of skin protection by UV radiation [70]. Abnormal melanin can result from the changes anywhere in the pathway of synthesis either due to abnormal tyrosinase or due to the deficits caused by the transfer of melanosomes to keratinocytes $[71,72]$. The role of tyrosinase is different in different kingdoms, as in invertebrates they play a crucial task in defense and sclerotization reactions [73]. Whereas in microbial world its use is still unknown, melanin helps in the formation of reproductive organs and spores and in cell wall protection after physical damage [25]. Agaricus bisporus [74], Pycnoporus sanguineus [20], Aspergillus oryzae [75], Aspergillus flavipes [76], Neurospora crassa [77], and Lentinula edodes [18] show tyrosinase activity and thus act as sources for its retrieval.

\section{Pharmaceutical Importance of Tyrosinase in Melanin Biosynthesis}

Tyrosinase is known to be the key enzyme in melanin biosynthesis. Melanin is the most important pigment synthesized through a physiological process called melanogenesis in membrane-bound subcellular organelles, the melanosomes which remain present in black; dendritic cells of the skin are called melanocytes and their activity is the major determinant of the color of the hair and skin. Melanocytes are produced in the neural crest and travel to the basal layer of the epidermis and the hair matrices during embryogenesis. They play a pivotal role in protecting the skin from dreadful UV light by absorbing UV rays of sunlight and removing reactive oxygen species $[78,79]$. Due to exposure to sunlight, the number of melanosomes increases, thus increasing their melanin content and their transfer to keratinocytes. Melanin is a class of compounds which is also found in the plant, animal, and Protista kingdoms, where it serves predominantly as a pigment and is synthesized within melanosomes, a membrane-bound granule [78]. The melanin biosynthetic pathway is outlined in Figures 3(a) and 3(b) where tyrosinase catalyses hydroxylation of the amino acid tyrosine to 3,4dhydroxyphenylalanine (DOPA) by monophenolase action and oxidation of DOPA into $o$-dopaquinone by diphenolase action. This $o$-quinone is transformed into melanin in a series of nonenzymatic reactions [80, 81].

There are two types of melanin pigments that can be produced by the melanocytes, namely, "eumelanin" (black or brown) and "pheomelanin" (red or yellow) as shown in Figure 4 . Both amount and type genes operate under incomplete dominance [79].

Several genes expression that is MCIR, SLC45A2, ASIP, TYR, OCA2, and SLC24A5 is involved in the variation of skin tones in humans due to difference in fraction in melanin units between Europeans and Africans. Number of melanocytes cells are very much similar in individuals of different racial groups as shown in Figure 5. Thus the type of melanin production depends on the functioning of the melanocytes, people with darker skin are just genetically programmed to continuously produce higher levels of melanin even without exposure to UV light and their melanosomes remains singular, however in case of individuals with fair skin colour, melanosomes packed itself in the form of membrane-bound organelles [78-80].

Tyrosinases play an important role in melanogenesis (i.e., biosynthesis of melanin pigments also known as pigmentation). In the reaction, tyrosine is first oxidized to dopaquinone, which either cyclises to give a dihydroxyindole precursor of black or brownish eumelanins or reacts with cysteine to give a precursor of reddish brown pheomelanin [81]. Overactivity of this enzyme leads to overproduction of melanin leading to hyperpigmentation of the skin and underactivity leads to disorders such as vitiligo (depigmentation spots that occur of the skin) and whitening of hair. Some commercially available chemical and fungal derived skin-lightening agents have been proven to have chronic, cytotoxic, and mutagenic effects in humans $[82,83]$.

\section{Microbial Tyrosinase for Manufacture of L-DOPA in Pharmaceutical Industries}

L-Dihydroxy phenylalanine is a naturally occurring dietary supplement and psychoactive drug found in certain kinds of food and herbs (e.g., Mucuna pruriens or velvet bean) and is synthesized from the amino acid L-tyrosine in the mammalian body and brain. L-DOPA is a precursor of the production of dopamine by the central nervous system. Thus, L-DOPA is used as a potent drug for the treatment of Parkinson's disease and is also used to control the myocardium neurogenic injury [84]. Production of L-DOPA using Ltyrosine as substrate and L-ascorbate as reducing agent with the enzyme tyrosinase (EC 1.14.18.1) as biocatalyst has been studied [85]. Manufacturing L-DOPA using microbial tyrosinases in batch reactors ranges from 1.44 to $54 \mathrm{mg}$ [86]. But the production seems to be much less due to two factors; that is, firstly, addition of L-tyrosine is incomplete, with less than $30 \%$ of it being consumed during the process. Secondly, due to side reactions and reversible process intermediates, dopaquinone, leukodopachrome, and dopachrome are produced with melanin which is exterminated by the addition of L-ascorbate in similar concentration to tyrosine [87]. Ates [88] used microbial tyrosinase in $\mathrm{Cu}$-alginate gels in continuous and batch systems. The total market volume of L-DOPA is 

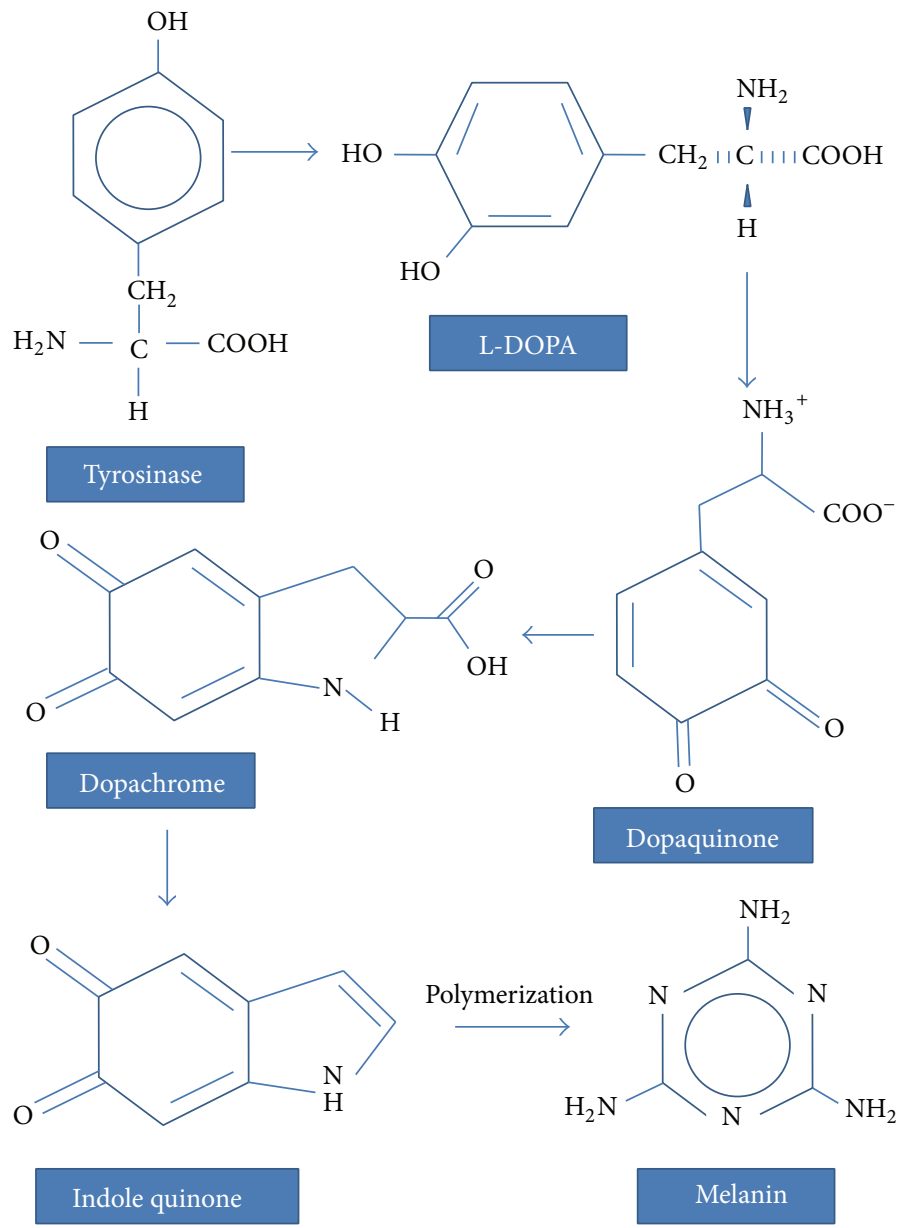

FIgURE 3: Melanin biosynthetic pathway.

$\$ 101$ billion per year worldwide (US patent number 5837504 , 1998) and thus alternative production methods are still being searched for the production of this drug. The world market for L-DOPA is increasing as indicated by an upliftment of 250 tons per year [89]. In the last few decades, enzymatic production of L-DOPA using microbes from Erwinia herbicola has been industrialized [88]. The other microbial sources have been reported earlier for the construction of tyrosinases which convert L-DOPA using as substrate Ltyrosine, including Erwinia herbicola [81], Aspergillus oryzae [90], Yarrowia lipolytica [91], Acremonium rutilum [92], and Bacillus sp. [93]. Industrial production of L-DOPA by the action of immobilized tyrosinase is shown in Figure 6.

\section{Industrial Application of Tyrosinase}

Chen et al. [94] reported the novel use of tyrosinase for the in vitro conjugation of the protein gelatin to the polysaccharide chitosan. Hydroxytyrosol, a potent antioxidant abundant in olives, was also synthesized with tyrosinase from tyrosol. Tyrosinase is used as a potential prodrug for treating melanoma where patients were successfully treated via tyrosinase activity $[95,96]$. Anghileri et al. [97] utilize microbial tyrosinase to produce conjugates from sericin, a peptide found in the wastewater of silk textile industries. Recently,
EMPA, a transdisciplinary research and service institution, has introduced methods for the recombinant production of bacterial tyrosinase; these are utilized for the formation of biomaterials such as cross-linked proteins and melanin, for example, recombinant Verrucomicrobium. Spinosum tyrosinase protein is used to produce tailor-made melanin and other polyphenolic materials using various phenols and catechols as starting materials and these have a wide application as they can be used to develop organic semiconductors or in photovoltaics. The tyrosinase enzyme can also be used to produce cross-linked proteins, allowing enzyme biocatalysts such as lipase to be easily recycled.

\section{Discovery and Quantification of Phenolic Compounds}

In view of the major concerns regarding toxicity, considerable attention has been given to the reliable quantification of phenols in complex environmental matrices. Phenolic compounds are present in the wastewater of a number of industries such as coal conversion, resin and plastics, petroleum refineries, textiles, dyes, iron and steel, and pulp and paper [98]. Phenols are toxic pollutants in industrial wastes imposing several risks on human health and some are suspected carcinogens. In addition, phenol causes 


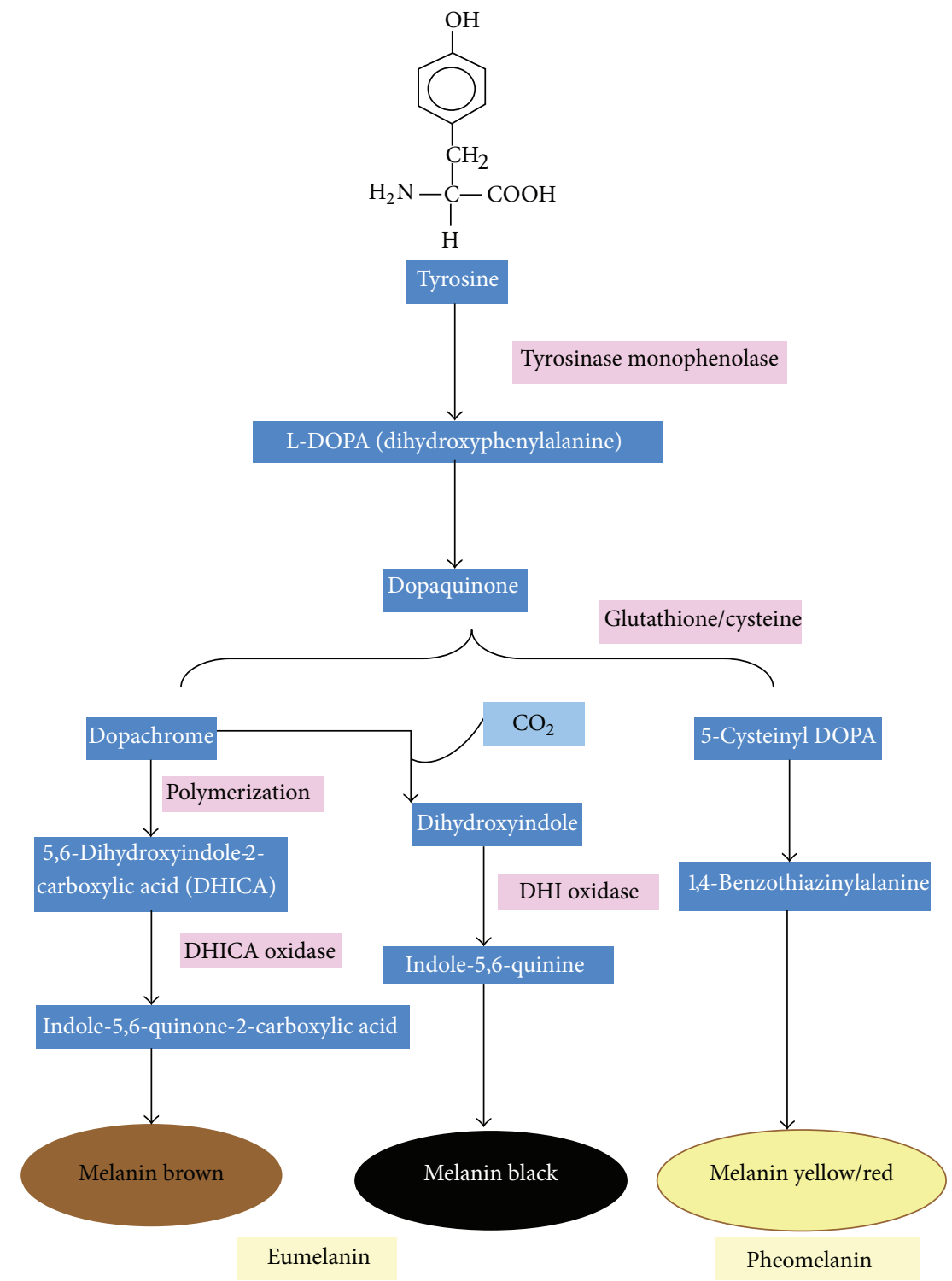

FIGURE 4: Production of different pigments by melanosomes.

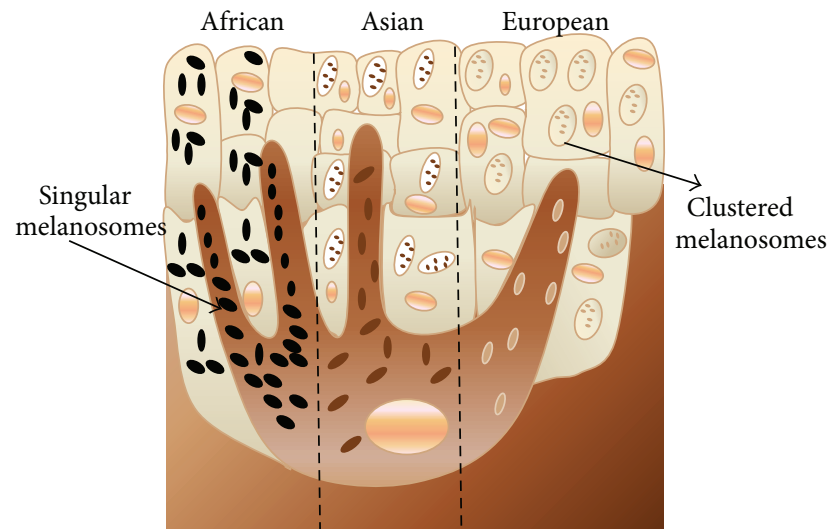

FIGURE 5: Structure or melanosome distribution for different racial groups. coloration of the receiving waters and it is, therefore, essential to decontaminate such compound [99]. Several researchers have studied the use of enzymes in wastewater treatment. The application of a polyphenol oxidase enzyme such as tyrosinase in removal of phenol and its derivatives has become very important and effective method [100]. The tyrosinase from S. antibioticus, for example, had activity on industrial pollutants such as 3- and 4-chlorophenols and 3- and 4fluorophenols [101]. The application of bacterial tyrosinase to the treatment of contaminated wastewaters has recently been reviewed and can be done either with tyrosinase producing stains or with the enzyme in an immobilized form as protagonist $[102,103]$. Tyrosinase offers the advantage over other enzyme systems that have been used for phenol removal in that molecular oxygen rather than hydrogen peroxide which is the oxidant, theoretically reducing the 


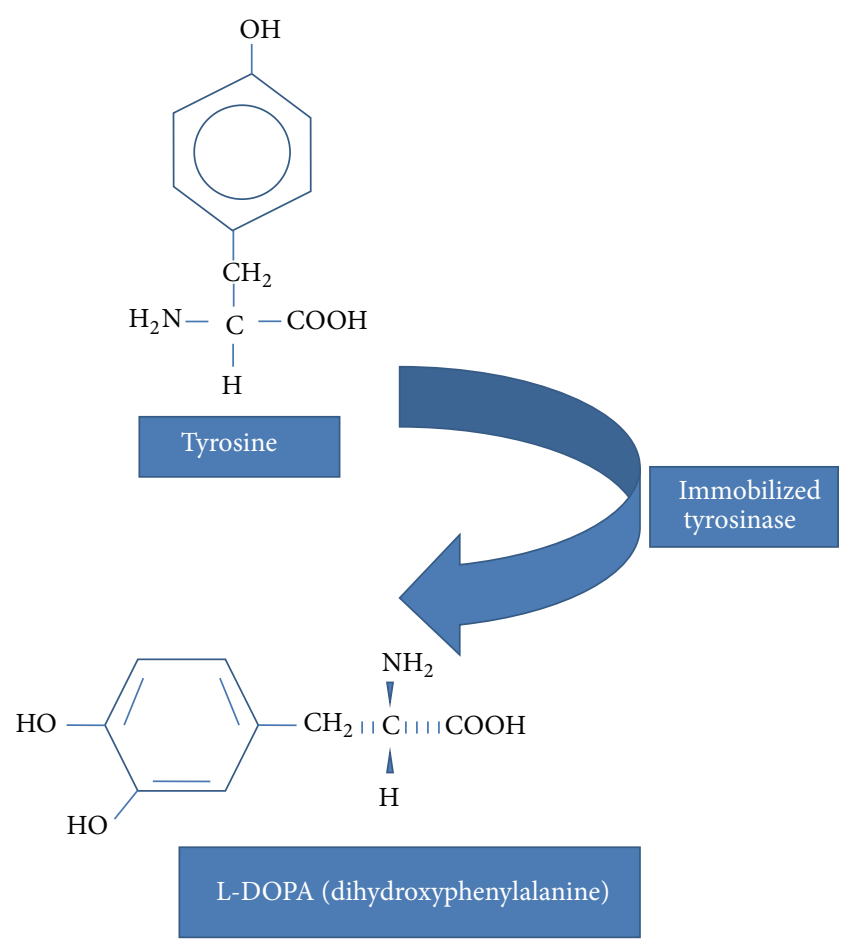

FIGURE 6: Industrial production of L-DOPA using of microbial tyrosinase.

potential cost of applying the technology [104]. Among many analytical methods used for fast monitoring of these phenolic compounds, electrochemical biosensors based on immobilized tyrosinase have received the major allocate of attention $[105,106]$. Traditionally, spectrophotometric or chromatographic methods are used for the detection of phenolic compounds. Certain new procedures (capillary electrophoresis, immunoassays, and biosensors) have been developed, which potentially provide better specificity, lower costs, and faster and simpler sample processing [107].

Tyrosinases catalyse conversion of phenolic substrate to quinine species that can be electrochemically reduced to allow low potential detection of phenolic analyte [108]. Different methods are utilized for the immobilization of tyrosinase with an electrochemical transducer such as adsorption [109], cross-linking [110], on the surface of electrodes, entrapment in polymer films and hydrogels [111], carbon paste matrix $[112,113]$ and graphite-epoxy composite electrodes [114]. Electropolymerization $[115,116]$, self-assembled monolayers [117, 118], silica sol-gel [9], alumina sol-gel [119], and nanoparticles [120] have also been applied for immobilization of tyrosinase for the detection of phenolic compounds. Tembe et al. [121] introduced an electrochemical biosensor for the determination of catechol where the enzyme was entrapped in agaroseguar gum composite biopolymer matrix. The use of the tyrosinase-polysaccharide bioelectrode for monitoring environmental pollution can be initiated as composite material (agarose and guar gum) has a good film forming and adhesion ability, as well as being nontoxic and biocompatible, thus increasing its use for tyrosinase entrapment and subsequent session fabrication. Seetharam and Saville [122] studied the degradation of phenol by tyrosinase immobilized on chemically modified sodium aluminosilicate $(\mathrm{NaA})$, calcium aluminosilicate $(\mathrm{CaA})$, and silica gel which can be reused repeatedly without any decrease in performance. Biosensors based on tyrosinases were designed for measuring phenols, polyphenols, and pesticides. Tyrosinases are also applied in biosensors and microarrays through immobilization [123]; for example, detection of toxic phenolic compounds [124] with consortium to other enzyme (glucose dehydrogenase) [125]. "Class selective" enzyme electrodes based on tyrosinase are used for semiquantitative field screening as well as detectors for liquid chromatography providing quantitation of the individual substrates [126]. Tyrosinase biosensors are also used for monitoring substrate carbonates, pesticides [127], cyanide, organophosphates, or toxic metals [128], where they measure various toxins due to the perturbation and modulation of the enzyme activity. Thus these act as early warning poison detectors.

\section{Tyrosinase Biosensor Based on Interdigitated Electrodes for Herbicides Determination}

In recent year, many amperometric biosensors based on the inhibition of the activity of tyrosinase enzymes have been used for the determination of triazine and phenylurea herbicides in the environment. Use of herbicides is persistent in spite of the danger it causes to the environment, as it is widely used due to its low environmental persistence but it contributes to the high acute toxicity. They cause a potent hazard to human health as their presence can be detected in surface and ground water. Different techniques are used extensively for the detection and quantitative determination of the toxic levels. Typically, liquid chromatography (LC) or gas chromatography (GC) is used but nowadays electrochemical enzyme sensors are also considered an alternative method to the conventional spectrometric techniques for pollutant determination due to their simplified sample. To enhance the biosensor response and sensitivity $\mathrm{Fe}_{3} \mathrm{O}_{4}$ nanoparticles together with immobilized alkaline phosphates into a solgel/chitosan biosensor membrane have been incorporated. These nanoparticles used in electrochemical biosensors have the ability to provide a favorable microenvironment for biomolecules such as proteins to exchange electrons directly with an electrode [129]. Similarly, different enzyme based biosensors involving laccase $[130,131]$, tyrosinase [132], glucose oxidase [133, 134], horseradish peroxidase [135], and $\mathrm{Fe}_{3} \mathrm{O}_{4}$ nanoparticles have been used for the construction of electrochemical biosensors. Tyrosinase electrode is also employed to monitor phenolic and catecholic compounds; it is one of the effective transducers for detection of phenols or catechols $[85,136,137]$.

\section{Manufacturing of Cross-Linked Biopolymers}

Food industry is continuously developing new biopolymers with special properties not only for their use as emulsifying 

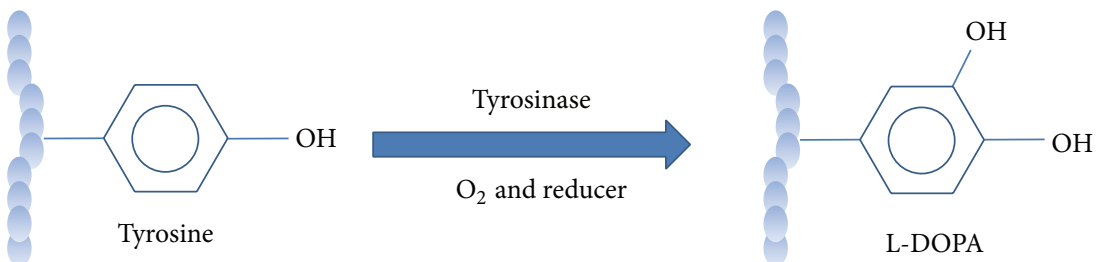

(a)
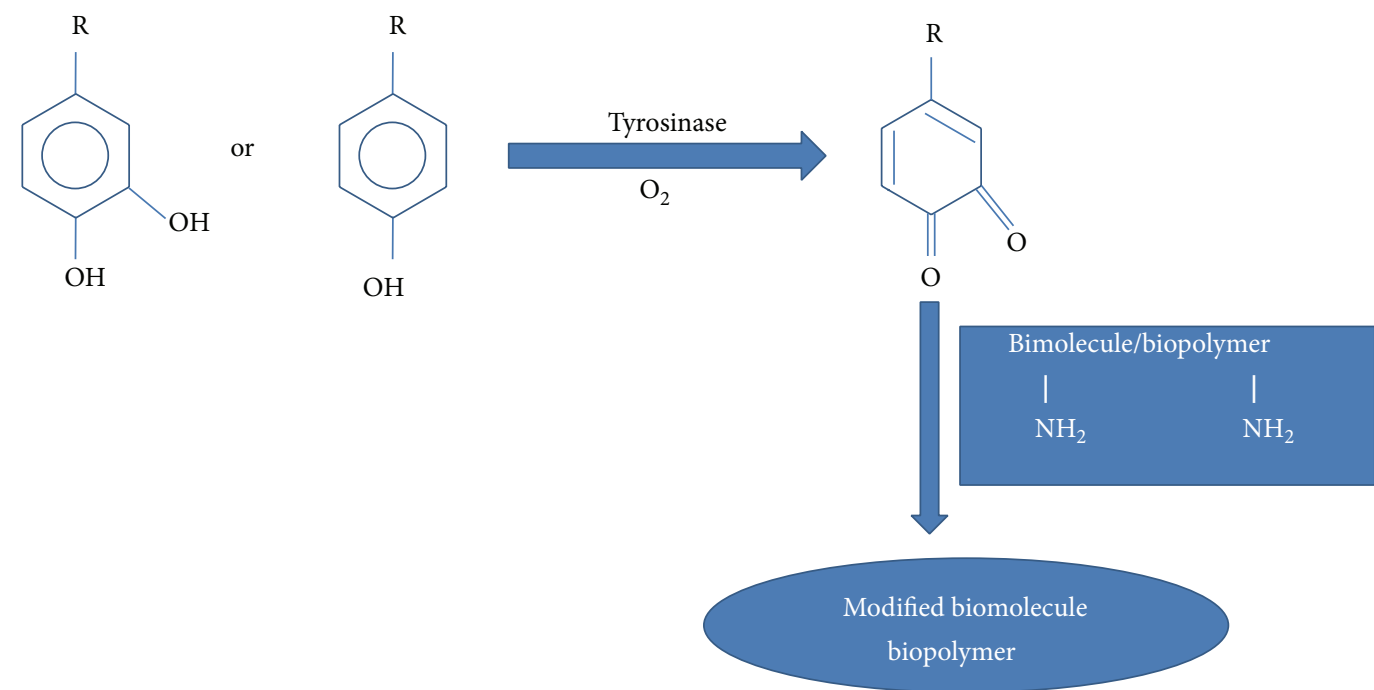

(b)

FIGURE 7: Transfer of tyrosine amino acids into DOPA by the action of tyrosinase in the presence of a reducer. (a) Oxidation of phenol or catechol derivatives into reactive $o$-quinones using tyrosinase, followed by the grafting of amino-functionalized biomolecules/biopolymer (b).

and thickening agents but also for the production of lowcalorie and low-fat foods. Different enzymes are used for hydrolyzing food biopolymers so as to improve product characteristics [138]. Cross-linked biopolymers modify the structural properties of the food matrix [139]. Similarly, enzymatic cross-linking and grafting of specific substances to the biopolymers can be used in the textile industry and for generation of novel biomaterials $[129,140]$. The mode of reaction opted by tyrosinase, a cross-linking enzyme for food biopolymers, is direct as it catalyses oxidation of monoand diphenols to $o$-diquinones utilizing p-coumaric acid ( $\mathrm{p}$ $\mathrm{CA}$ ) and caffeic acid and not ferulic acid (FA) reactive sites in carbohydrates and tyrosine in proteins, respectively [139]. Oxidative enzymes, tyrosinase, have the potential to crosslink food biopolymers [141]. Trichoderma reesei tyrosinase is found to be an efficient protein cross-linker, when compared to the $T$. hirsute laccase or to the tyrosinases of microbial origin. Selinheimo [142] reported the use of tyrosinase and laccase to generate food biopolymers with added functionalities or novel food structures from diverse raw materials. Quinones react nonenzymatically with nucleophilic moieties lysyl, tyrosyl, cysteinyl, and histidinyl residues of proteins [143-145]. They are susceptible to nucleophilic attack by free sulfhydryl and amino groups of amino acid side chains, resulting in formation of tyrosine-cysteine and tyrosinelysine cross-links in the protein structures [146]. Similarly, they couple to phenolic compounds to form dimeric phenolic conjugates [147]. Desentis-Mendoza et al. [148] reported improved in vitro antioxidation by polymerization of phenolic compounds. Oxidation of polyphenols via tyrosinase catalysis has been reported thus improving in vitro iron accessibility [149]. The cross-linking of biopolymers using tyrosinase is shown in Figure 7.

\section{Determination of Certain Compounds in Beverages}

Montereali et al. [150] reported the detection of polyphenols present in musts and wines through an amperometric biosensor based on the utilization of tyrosinase and laccase from Trametes versicolor. Both enzymes were immobilized on graphite screen-printed electrodes modified with ferrocene. These biosensors exhibited a good sampling behavior compared to that obtained from spectrophotometric analysis but enzymatic activity was prevented due to the presence of $\mathrm{SO}_{2}$ [151]. Tyrosinases are also selectively removed byproducts contaminant in industrial fermentation processes [152].

14.1. In Cereal Processing. The application of tyrosinases in cereal processing has been well studied as it can catalyze oxidation of phenolic compounds present in cereal proteins and polysaccharides by either producing linkages in or between 
polysaccharides or in between proteins and polysaccharides or proteins themselves. Kuninori et al. [153] described the effect of tyrosinase (extract of mushroom, rich in polyphenol oxidase) on wheat dough while tyrosinase-catalyzed formation of 2-S-cysteinyl-DOPA, 2,5-di-S-cysteinyl-DOPA, 6S-cysteinyl-DOPA, 5-S-cysteinyl-3, 4-DOPA, and di-DOPA cross-links has been characterized in gluten proteins [146, 154].

14.2. In Dairy Processing. In dairy products, cross-linking can be exploited for prevention of syneresis or to make a soft texture firmer. Hetero-cross-linking or cereal, milk, and meat biopolymers provide a probable means to produce novel food products with precise functionalities and characteristics. Tyrosinase improves functionalization of milk products, for example, tailoring antioxidation of biopolymers. Ito et al. [155] reported oxidation of the tyrosyl residues of dairy proteins whereas Halaouli et al. [20] reported the cross-linking of casein proteins. Furthermore, tyrosinases have been reported to induce partial cross-linking of whey proteins; for example, tyrosinase from $A$. bisporus could cross-link $\alpha$-lactalbumin [156].

14.3. In Meat Processing. Cross-linking enzymes play an essential role in tailoring the gelation properties of meat as gel formation ability and textural and binding properties of meat are vital in manufacturing meat products. Tyrosinases have recently been tested for processing of pork and chicken proteins $[157,158]$. Tyrosinase effectively improves the gel formation property of a $4 \%$ chicken breast myofibrillar protein suspension in presence of $0.35 \mathrm{M} \mathrm{NaCl}$ as well as improving the firmness of the homogenate gels containing a lowered amount of meat free of phosphate $[159,160]$.

\section{Other Applications}

Application of tyrosinase in cell culture has also implicated the wide acceptance of its catalytic property, as it helps nerve cells to grow. The process includes stamping of the tyrosinase enzyme onto plastic surfaces, which causes in situ formation of thin films of melanin. It may be useful in the prevention of bacterial contamination, as melanin has a bacteriostatic effect. Immobilization of tyrosinase is used to convert Ltyrosine to L-DOPA by entrapment into either polymer, natural polymer, or modified polystyrene or adsorption on nylon zeolite [161], glass beads, fuller's earth, and chitin activated with hexamethylenediamine [162]. Several studies reported the grafting of silk proteins onto chitosan via tyrosinase reactions specifying tailoring properties of polymers. Likewise, grafting of L-DOPA to wool fibers proteins has also been successfully carried out $[163,164]$. It is also used for the preparation of hydrogels for skin substitutes [165], matrices for drug delivery, and tissue engineering [166]. Aberg et al. [129] used tyrosinase for biocatalytic grafting of phenolic moieties or protein onto chitosan. Production of $o$-diphenols was done using mushroom tyrosinase from Agaricus bisporus which was immobilized on commercially available epoxy-resin EupergitC250L and then coated using layer-by-layer method (LbL) [167]. The two novel heterogeneous biocatalysts have been characterized for their morphology and reusability. These biocatalysts were used for the efficient and selective synthesis of bioactive catechols under mild and environmentally friendly experimental conditions [168]. Tyrosinase and layer-by-layer supported tyrosinases are also used in the synthesis of lipophilic catechols. A significant antiviral activity has been observed in such derivatives which are characterized by antioxidant activity and long carbon alkyl side chains, suggesting the possibility of a new inhibition mechanism based on both redox and lipophilic properties [169].

\section{Conclusion}

There is an increasing demand for various enzymes in industries, in spite of their wide acceptance in the global market. Tyrosinase enzymes constitute one of the most important groups of commercial enzymes. These enzymes have ample utilization in industrial processes, such as pharmaceuticals and cosmetic and food industries. There are considerable reports indicating the great potential of this enzyme medicine, agricultural industries, and analytical and environmental purposes. It is also used to produce synthetic melanin which provides protection against radiation and is used as cation exchangers, drug carriers, antioxidants, antiviral agents, or immunogens. However, this review shows that microbial tyrosinase is a promising enzyme for pharmaceutical and food bioprocessing technology appraising the state of knowledge about its structure biochemical properties, melanin biosynthetic pathway, purification, and production. We conclude that much more research is necessary in these areas if microbial tyrosinases are to fulfill their industrial potential. In conclusion, more concrete studies of the found microbial tyrosinase with a human clinical point of view are required, and, in our experience, this often needs the help and cooperation of pharmaceutical, cosmetic, or bioprocessing companies.

\section{Conflict of Interests}

The authors declare that there is no conflict of interests regarding the publication of this paper.

\section{Acknowledgments}

The authors are thankful to Sarvajanik Jankalyan Parmarthik Nyas, People's Group, Bhopal, for laboratory facilities and to the Principal and Secretary of Saifia College of Science, Bhopal, for encouragement.

\section{References}

[1] D. A. Robb, "Tyrosinase," in Copper Proteins and Copper Enzymes, R. Lontie, Ed., pp. 207-241, CRC Press, Boca Raton, Fla, USA, 1984.

[2] J. R. Whitaker, "Polyphenol oxidase," in Food Enzymes: Structure and Mechanism, D. W. S. Wong, Ed., pp. 271-307, Chapman and Hall, New York, NY, USA, 1995.

[3] M. Rolff, J. Schottenheim, H. Decker, and F. Tuczek, "Copper- $\mathrm{O}_{2}$ reactivity of tyrosinase models towards external monophenolic 
substrates: molecular mechanism and comparison with the enzyme," Chemical Society Reviews, vol. 40, no. 7, pp. 40774098, 2011.

[4] V. P. S. dos Santos, L. M. C. Silvaa, A. M. Salgado, and K. S. Pereira, "Application of Agaricus bisporusextract for benzoate sodium detection based on tyrosinase inhibition for biosensor development," Chemical Engineering Transactions, vol. 32, pp. 66-70, 2013.

[5] A. Gradilone, E. Cigna, A. M. Agliano, and L. Frati, "Tyrosinase expression as a molecular marker for investigating the presence of circulating tumor cells in melanoma patients," Current Cancer Drug Targets, vol. 10, no. 5, pp. 529-538, 2010.

[6] S. Jawaid, T. H. Khan, H. M. I. Osborn, and N. A. O. Williams, "Tyrosinase activated melanoma prodrugs," Anti-Cancer Agents in Medicinal Chemistry, vol. 9, no. 7, pp. 717-727, 2009.

[7] E. Monogioudi, G. Faccio, M. Lille, K. Poutanen, J. Buchert, and M.-L. Mattinen, "Effect of enzymatic cross-linking of $\beta$-casein on proteolysis by pepsin," Food Hydrocolloids, vol. 25, no. 1, pp. 71-81, 2011.

[8] H. Claus and Z. Filip, "Behaviour of phenoloxidases in the presence of clays and other soil-related adsorbents," Applied Microbiology and Biotechnology, vol. 28, no. 4-5, pp. 506-511, 1988.

[9] Y.-S. Wang, S.-P. Tian, and Y. Xu, "Effects of high oxygen concentration on pro- and anti-oxidant enzymes in peach fruits during postharvest periods," Food Chemistry, vol. 91, no. 1, pp. 99-104, 2005.

[10] S.-Y. Seo, V. K. Sharma, and N. Sharma, "Mushroom tyrosinase: recent prospects," Journal of Agricultural and Food Chemistry, vol. 51, no. 10, pp. 2837-2853, 2003.

[11] T.-S. Chang, "An updated review of tyrosinase inhibitors," International Journal of Molecular Sciences, vol. 10, no. 6, pp. 24402475, 2009.

[12] S. Molloy, J. Nikodinovic-Runic, L. B. Martin et al., "Engineering of a bacterial tyrosinase for improved catalytic efficiency towards D-tyrosine using random and site directed mutagenesis approaches," Biotechnology and Bioengineering, vol. 110, no. 7, pp. 1849-1857, 2013.

[13] C. W. G. van Gelder, W. H. Flurkey, and H. J. Wichers, "Sequence and structural features of plant and fungal tyrosinases," Phytochemistry, vol. 45, no. 7, pp. 1309-1323, 1997.

[14] K. G. Strothkamp, R. L. Jolley, and H. S. Mason, "Quaternary structure of mushroom tyrosinase," Biochemical and Biophysical Research Communications, vol. 70, no. 2, pp. 519-524, 1976.

[15] K. Lerch, "Copper monooxygenases: tyrosinase and dopamine B-monooxygenase," in Metal Ions in Biological Systems, H. Sigel, Ed., pp. 143-186, Marcel Dekker, New York, NY, USA, 1983.

[16] K. Lerch, "Neurospora tyrosinase: structural, spectroscopic and catalytic properties," Molecular and Cellular Biochemistry, vol. 52, no. 2, pp. 125-138, 1983.

[17] L. A. Mueller, U. Hinz, and J.-P. Zrÿd, "Characterization of a tyrosinase from Amanita muscaria involved in betalain biosynthesis," Phytochemistry, vol. 42, no. 6, pp. 1511-1515, 1996.

[18] K. Kanda, T. Sato, S. Ishii, H. Enei, and S.-I. Ejiri, "Purification and properties of tyrosinase isozymes from the gill of Lentinus edodes fruiting body," Bioscience, Biotechnology and Biochemistry, vol. 60, no. 8, pp. 1273-1278, 1996.

[19] M. Nakamura, T. Nakajima, Y. Ohba, S. Yamauchi, B. R. Lee, and E. Ichishima, "Identification of copper ligands in Aspergillus oryzae tyrosinase by site-directed mutagenesis," Biochemical Journal, vol. 350, no. 2, pp. 537-545, 2000.
[20] S. Halaouli, M. Asther, K. Kruus et al., "Characterization of a new tyrosinase from Pycnoporus species with high potential for food technological applications," Journal of Applied Microbiology, vol. 98, no. 2, pp. 332-343, 2005.

[21] R. O. de Faria, V. R. Moure, W. Balmant, M. A. L. D. A. Amazonas, N. Krieger, and D. A. Mitchell, "The tyrosinase produced by Lentinula boryana (Berk. \& Mont.) pegler suffers substrate inhibition by L-DOPA," Food Technology and Biotechnology, vol. 45, no. 3, pp. 334-340, 2007.

[22] G. Della-Cioppa, S. J. Garger, R. B. Holtz, M. J. Mcculloch, and G. G. Sverlow, "Method for making stable extracellular tyrosinase and synthesis of polyphenolic polymers therefrom," US Patent 5801047, 1998.

[23] G. Della-Cioppa, S. J. Garger, G. G. Sverlow, T. H. Turpen, L. K. Grill, and M. R. Chedekal, "Melanin production by Streptomyces," US Patent 5814495, 1998.

[24] Z. Liu, Y. Liu, H. Yang, Y. Yang, G. Shen, and R. Yu, "A phenol biosensor based on immobilizing tyrosinase to modified coreshell magnetic nanoparticles supported at a carbon paste electrode," Analytica Chimica Acta, vol. 533, no. 1, pp. 3-9, 2005.

[25] H. Claus and H. Decker, "Bacterial tyrosinases," Systematic and Applied Microbiology, vol. 29, no. 1, pp. 3-14, 2006.

[26] A. M. McMahon, E. M. Doyle, S. Brooks, and K. E. O’Connor, "Biochemical characterisation of the coexisting tyrosinase and laccase in the soil bacterium Pseudomonas putida F6," Enzyme and Microbial Technology, vol. 40, no. 5, pp. 1435-1441, 2007.

[27] Y. Matoba, T. Kumagai, A. Yamamoto, H. Yoshitsu, and M. Sugiyama, "Crystallographic evidence that the dinuclear copper center of tyrosinase is flexible during catalysis," The Journal of Biological Chemistry, vol. 281, no. 13, pp. 8981-8990, 2006.

[28] A. Janovitz-Klapp, F. Richard, and J. Nicolas, "Polyphenoloxidase from apple, partial purification and some properties," Phytochemistry, vol. 28, no. 11, pp. 2903-2907, 1989.

[29] J. Raymond, N. Rakariyatham, and J. L. Azanza, "Purification and some properties of polyphenoloxidase from sunflower seeds," Phytochemistry, vol. 34, no. 4, pp. 927-931, 1993.

[30] J.-L. Lee, K.-H. Kong, and S.-H. Cho, "Purification and characterization of tyrosinase from Solanum melongena," Journal of Biochemistry and Molecular Biology, vol. 30, no. 2, pp. 150-156, 1997.

[31] M. Friedman, "Food browning and its prevention: an overview," Journal of Agricultural and Food Chemistry, vol. 44, no. 3, pp. 631-653, 1996.

[32] I. Kubo and I. Kinst-Hori, “Tyrosinase inhibitors from cumin," Journal of Agricultural and Food Chemistry, vol. 46, no. 12, pp. 5338-5341, 1998.

[33] N. Rani, B. Joy, and T. E. Abraham, "Cell suspension cultures of Portulaca grandiflora. as potent catalysts for biotransformation of L-tyrosine into L-DOPA, an anti-Parkinson's drug," Pharmaceutical Biology, vol. 45, no. 1, pp. 48-53, 2007.

[34] A. M. Mayer, "Polyphenol oxidases in plants and fungi: going places? A review," Phytochemistry, vol. 67, no. 21, pp. 2318-2331, 2006.

[35] E. Jaenicke and H. Decker, "Tyrosinases from crustaceans form hexamers," Biochemical Journal, vol. 371, no. 2, pp. 515-523, 2003.

[36] R. L. Jolley Jr., D. A. Robb, and H. S. Mason, “The multiple forms of mushroom tyrosinase: association-dissociation phenomena," The Journal of Biological Chemistry, vol. 244, no. 6, pp. 15931599, 1969. 
[37] J. Wu, H. Chen, J. Gao, X. Liu, W. Cheng, and X. Ma, “Cloning, characterization and expression of two new polyphenol oxidase cDNAs from Agaricus bisporus," Biotechnology Letters, vol. 32, no. 10, pp. 1439-1447, 2010.

[38] K. Nishioka, "Particulate tyrosinase of human malignant melanoma. Solubilization, purification following trypsin treatment, and characterization," European Journal of Biochemistry, vol. 85, no. 1, pp. 137-146, 1978.

[39] P. F. T. Vaughan, R. Eason, J. Y. Paton, and G. A. Ritchie, "Molecular weight and amino acid composition of purified spinach beet phenolase," Phytochemistry, vol. 14, no. 11, pp. 2383-2386, 1975.

[40] E. I. Solomon, U. M. Sundaram, and T. E. Machonkin, "Multicopper oxidases and oxygenases," Chemical Reviews, vol. 96, no. 7, pp. 2563-2605, 1996.

[41] D. E. Wilcox, A. G. Porras, Y. T. Hwang, K. Lerch, M. E. Winkler, and E. I. Solomon, "Substrate analogue binding to the coupled binuclear copper active site in tyrosinase," Journal of the American Chemical Society, vol. 107, no. 13, pp. 4015-4027, 1985.

[42] Á. Sánchez-Ferrer, J. N. Rodríguez-López, F. García-Cánovas, and F. García-Carmona, "Tyrosinase: a comprehensive review of its mechanism," Biochimica Biophysica Acta, vol. 1247, no. 1, pp. 1-11, 1995.

[43] T. G. Pridham, P. Anderson, C. Foley, L. A. Lindenfelser, C. W. Hesseltine, and R. G. Benedict, "A selection of media for maintenance and taxonomic study of Streptomyces," Antibiotics Annual, vol. 57, pp. 947-953, 1957.

[44] M. Sendovski, M. Kanteev, V. S. Ben-Yosef, N. Adir, and A. Fishman, "First structures of an active bacterial tyrosinase reveal copper plasticity," Journal of Molecular Biology, vol. 405, no. 1, pp. 227-237, 2011.

[45] M. Fairhead and L. Thöny-Meyer, "Role of the C-terminal extension in a bacterial tyrosinase," The FEBS Journal, vol. 277, no. 9, pp. 2083-2095, 2010.

[46] Y. Kawamura-Konishi, M. Tsuji, S. Hatana et al., "Purification, characterization, and molecular cloning of tyrosinase from Pholiota nameko," Bioscience, Biotechnology and Biochemistry, vol. 71, no. 7, pp. 1752-1760, 2007.

[47] Y. Fujita, Y. Uraga, and E. Ichisima, "Molecular cloning and nucleotide sequence of the protyrosinase gene, melO, from Aspergillus orzyae and expression of the gene in yeast cells," Biochimica et Biophysica Acta, vol. 1261, no. 1, pp. 151-154, 1995.

[48] J. C. Espín, P. A. García-Ruiz, J. Tudela, and F. García-Cánovas, "Study of stereospecificity in mushroom tyrosinase," Biochemical Journal, vol. 331, no. 2, pp. 547-551, 1998.

[49] A. Sánchez-Ferrer, J. Villalba, and F. García-Carmona, “Triton $\mathrm{X}-114$ as a tool for purifying spinach polyphenol oxidase," Phytochemistry, vol. 28, no. 5, pp. 1321-1325, 1989.

[50] Á. Sánchez-Ferrer, R. Bru, and F. García-Carmona, "Partial purification of a thylakoid-bound enzyme using temperatureinduced phase partitioning," Analytical Biochemistry, vol. 184, no. 2, pp. 279-282, 1990.

[51] J. D. Laskin and L. A. Piccinini, "Tyrosinase isozyme heterogeneity in differentiating B16/C3 melanoma," The Journal of Biological Chemistry, vol. 261, no. 35, pp. 16626-16635, 1986.

[52] J. Cabanes, F. García-Cánovas, J. A. Lozano, and F. GarcíaCarmona, "A kinetic study of the melanization pathway between L-tyrosine and dopachrome," Biochimica et Biophysica Acta, vol. 923, no. 2, pp. 187-195, 1987.

[53] J. C. Espín, R. Varón, L. G. Fenoll et al., "Kinetic characterization of the substrate specificity and mechanism of mushroom tyrosinase," European Journal of Biochemistry, vol. 267, no. 5, pp. 1270-1279, 2000.

[54] V. J. Hearing and M. Jiménez, "Mammalian tyrosinase-the critical regulatory control point in melanocyte pigmentation," International Journal of Biochemistry, vol. 19, no. 12, pp. 11411147, 1987.

[55] X. Wan, B. Chai, Y. Liao et al., "Molecular and biochemical characterization of a distinct tyrosinase involved in melanin production from Aeromonas media," Applied Microbiology and Biotechnology, vol. 82, no. 2, pp. 261-269, 2009.

[56] F. Gandía-Herrero, F. García-Carmona, and J. Escribano, "Purification and characterization of a latent polyphenol oxidase from beet root (Beta vulgaris L.)," Journal of Agricultural and Food Chemistry, vol. 52, no. 3, pp. 609-615, 2004.

[57] E. Selinheimo, D. NiEidhin, C. Steffensen et al., "Comparison of the characteristics of fungal and plant tyrosinases," Journal of Biotechnology, vol. 130, no. 4, pp. 471-480, 2007.

[58] L. G. Fenoll, M. J. Peñalver, J. N. Rodríguez-López, R. Varón, F. García-Cánovas, and J. Tudela, “Tyrosinase kinetics: discrimination between two models to explain the oxidation mechanism of monophenol and diphenol substrates," The International Journal of Biochemistry \& Cell Biology, vol. 36, no. 2, pp. 235246, 2004.

[59] F. García-Molina, M. J. Peñalver, J. N. Rodríguez-López, F. García-Cánovas, and J. Tudela, "Enzymatic method with polyphenol oxidase for the determination of cysteine and $N$-acetylcysteine," Journal of Agricultural and Food Chemistry, vol. 53, no. 16, pp. 6183-6189, 2005.

[60] C. E. Birse and A. J. Clutterbuck, " $N$-acetyl-6-hydroxytryptophan oxidase, a developmentally controlled phenol oxidase from Aspergillus nidulans," Journal of General Microbiology, vol. 136, no. 9, pp. 1725-1730, 1990.

[61] V. Shuster and A. Fishman, "Isolation, cloning and characterization of a tyrosinase with improved activity in organic solvents from Bacillus megaterium," Journal of Molecular Microbiology and Biotechnology, vol. 17, no. 4, pp. 188-200, 2009.

[62] M. Ito and K. Oda, "An organic solvent resistant tyrosinase from Streptomyces sp. REN-21: purification and characterization," Bioscience, Biotechnology and Biochemistry, vol. 64, no. 2, pp. 261-267, 2000.

[63] E. Selinheimo, M. Saloheimo, E. Ahola et al., "Production and characterization of a secreted, C-terminally processed tyrosinase from the filamentous fungus Trichoderma reesei," The FEBS Journal, vol. 273, no. 18, pp. 4322-4335, 2006.

[64] H. Kamahldin, R. J. Ferdous, K. Ali-Asghar, and S. B. Shahrzad, "Purification of tyrosinase from edible mushroom," Iranian Journal of Biotechnology, vol. 2, no. 3, pp. 189-194, 2004.

[65] S. Koga, M. Nakano, and S. Tero-Kubota, "Generation of superoxide during the enzymatic action of tyrosinase," Archives of Biochemistry and Biophysics, vol. 292, no. 2, pp. 570-575, 1992.

[66] J. C. Espín, R. Varón, J. Tudela, and F. García-Cánovas, "Kinetic study of the oxidation of 4-hydroxyanisole catalyzed by tyrosinase," Biochemistry and Molecular Biology International, vol. 41, no. 6, pp. 1265-1276, 1997.

[67] S. Bouchilloux, P. Mcmahill, and H. S. Mason, "The multiple forms of mushroom tyrosinase. Purification and molecular properties of the enzymes," The Journal of Biological Chemistry, vol. 238, pp. 1699-1707, 1963.

[68] Y. Fan and W. H. Flurkey, "Purification and characterization of tyrosinase from gill tissue of Portabella mushrooms," Phytochemistry, vol. 65, no. 6, pp. 671-678, 2004. 
[69] H. J. Wichers, Y. A. M. Gerritsen, and C. G. J. Chapelon, "Tyrosinase isoforms from the fruitbodies of Agaricus bisporus," Phytochemistry, vol. 43, no. 2, pp. 333-337, 1996.

[70] V. del Marmol and F. Beermann, "Tyrosinase and related proteins in mammalian pigmentation," FEBS Letters, vol. 381, no. 3, pp. 165-168, 1996.

[71] F. Solano, S. Briganti, M. Picardo, and G. Ghanem, "Hypopigmenting agents: an updated review on biological, chemical and clinical aspects," Pigment Cell Research, vol. 19, no. 6, pp. 550571, 2006.

[72] K. Ray, M. Chaki, and M. Sengupta, "Tyrosinase and ocular diseases: some novel thoughts on the molecular basis of oculocutaneous albinism type 1," Progress in Retinal and Eye Research, vol. 26, no. 4, pp. 323-358, 2007.

[73] M. Sugumaran, "Comparative biochemistry of eumelanogenesis and the protective roles of phenoloxidase and melanin in insects," Pigment Cell Research, vol. 15, no. 1, pp. 2-9, 2002.

[74] A. A. Khan, S. Akhtar, and Q. Husain, "Simultaneous purification and immobilization of mushroom tyrosinase on an immunoaffinity support," Process Biochemistry, vol. 40, no. 7, pp. 2379-2386, 2005.

[75] E. Ichishima, H. Maeba, T. Amikura, and H. Sakata, "Multiple forms of protyrosinase from Aspergillus oryzae and their mode of activation at pH 3.0," Biochimica et Biophysica Acta, vol. 786, no. 1-2, pp. 25-31, 1984.

[76] G. S. Gukasyan, "Purification and some properties of tyrosinase from Aspergillus flavipes 56003," Biochemistry, vol. 64, no. 4, pp. 417-420, 1999.

[77] M. Fling, N. H. Horowitz, and S. F. Heinemann, "The isolation and properties of crystalline tyrosinase from Neurospora," The Journal of Biological Chemistry, vol. 238, pp. 2045-2053, 1963.

[78] Y.-J. Kim and H. Uyama, "Tyrosinase inhibitors from natural and synthetic sources: structure, inhibition mechanism and perspective for the future," Cellular and Molecular Life Sciences, vol. 62, no. 15, pp. 1707-1723, 2005.

[79] Summers, "A lightening tour of skin brightening option," South African Pharmaceutical and Cosmetic Review, vol. 33, no. 6, pp. 29-30, 2006.

[80] N. Baurin, E. Arnoult, T. Scior, Q. T. Do, and P. Bernard, "Preliminary screening of some tropical plants for anti-tyrosinase activity," Journal of Ethnopharmacology, vol. 82, no. 2-3, pp. 155$158,2002$.

[81] H. S. Mason, "The chemistry of melanin: III. Mechanism of the oxidation of trihydroxyphenylalanine by tyrosinase," The Journal of Biological Chemistry, vol. 172, pp. 83-99, 1948.

[82] K.-H. Wang, R.-D. Lin, F.-L. Hsu et al., "Cosmetic applications of selected traditional Chinese herbal medicines," Journal of Ethnopharmacology, vol. 106, no. 3, pp. 353-359, 2006.

[83] O. Nerya, J. Vaya, R. Musa, S. Izrael, R. Ben-Arie, and S. Tamir, "Glabrene and isoliquiritigenin as tyrosinase inhibitors from licorice roots," Journal of Agricultural and Food Chemistry, vol. 51, no. 5, pp. 1201-1207, 2003.

[84] Ikram-ul-Haq, S. Ali, and M. A. Qadeer, "Biosynthesis of LDOPA by Aspergillus oryzae," Bioresource Technology, vol. 85, no. 1, pp. 25-29, 2002.

[85] V. C. Sanz, M. L. Mena, A. González-Cortés, P. Yáñez-Sedeño, and J. M. Pingarrón, "Development of a tyrosinase biosensor based on gold nanoparticles-modified glassy carbon electrodes: application to the measurement of a bioelectrochemical polyphenols index in wines," Analytica Chimica Acta, vol. 528, no. 1, pp. 1-8, 2005.
[86] P. Pialis and B. A. Saville, "Production of L-DOPA from tyrosinase immobilized on nylon 6,6: enzyme stability and scaleup," Enzyme and Microbial Technology, vol. 22, no. 4, pp. 261-268, 1998.

[87] S. Ates, E. Cortenlioglu, E. Bayraktar, and U. Mehmetoglu, "Production of L-DOPA using Cu-alginate gel immobilized tyrosinase in a batch and packed bed reactor," Enzyme and Microbial Technology, vol. 40, no. 4, pp. 683-687, 2007.

[88] T. Koyanagi, T. Katayama, H. Suzuki, H. Nakazawa, K. Yokozeki, and H. Kumagai, "Effective production of 3,4-dihydroxyphenylL (L-DOPA) with Erwinia herbicola cells carrying a mutant transcriptional regulator TyrR," Journal of Biotechnology, vol. 115, no. 3, pp. 303-306, 2005.

[89] T. Katayama and H. Kumagai, "L-DOPA, microbial production," in Encyclopedia of Industrial Biotechnology Bioprocess, Bioseparation, and Cell Technology, pp. 1-4, 2010.

[90] Ikram-ul-Haq and S. Ali, "Mutation of Aspergillus oryzae for improved production of 3, 4-dihydroxy phenyl-L-alanine ( $\mathrm{L}$ DOPA) from L-tyrosine," Brazilian Journal of Microbiology, vol. 37, no. 1, pp. 78-86, 2006.

[91] S. Ali, J. L. Shultz, and Ikram-ul-Haq, "High performance microbiological transformation of L-tyrosine to L-DOPA by Yarrowia lipolytica NRRL-143," BMC Biotechnology, vol. 7, article 50, 2007.

[92] R. Krishnaveni, V. Rathod, M. S. Thakur, and Y. F. Neelgund, "Transformation of L-tyrosine to L-DOPA by a novel fungus, Acremonium rutilum, under submerged fermentation," Current Microbiology, vol. 58, no. 2, pp. 122-128, 2009.

[93] S. N. Surwase and J. P. Jadhav, "Bioconversion of L-tyrosine to LDOPA by a novel bacterium Bacillus sp. JPJ," Amino Acids, vol. 41, no. 2, pp. 495-506, 2011.

[94] T. Chen, H. D. Embree, L.-Q. Wu, and G. F. Payne, "In vitro protein-polysaccharide conjugation: tyrosinase-catalyzed conjugation of gelatin and chitosan," Biopolymers, vol. 64, no. 6, pp. 292-302, 2002.

[95] M. E. Morrison, M. J. Yagi, and G. Cohen, "In vitro studies of 2,4-dihydroxyphenylalanine, a prodrug targeted against malignant melanoma cells," Proceedings of the National Academy of Sciences of the United States of America, vol. 82, no. 9, pp. 29602964, 1985.

[96] A. M. Jordan, T. H. Khan, H. M. I. Osborn, A. Photiou, and P. A. Riley, "Melanocyte-directed enzyme prodrug therapy (MDEPT): development of a targeted treatment for malignant melanoma," Bioorganic \& Medicinal Chemistry, vol. 7, no. 9, pp. 1775-1780, 1999.

[97] A. Anghileri, R. Lantto, K. Kruus, C. Arosio, and G. Freddi, "Tyrosinase-catalyzed grafting of sericin peptides onto chitosan and production of protein-polysaccharide bioconjugates," Journal of Biotechnology, vol. 127, no. 3, pp. 508-519, 2007.

[98] C. Brasquet, E. Subrenat, and P. le Cloirec, "Removal of phenolic compounds from aqueous solution by activated carbon cloths," Water Science and Technology, vol. 39, no. 10-11, pp. 201-205, 1999.

[99] N. Singh and J. Singh, "An enzymatic method for removal of phenol from industrial effluent," Preparative Biochemistry \& Biotechnology, vol. 32, no. 2, pp. 127-133, 2002.

[100] K. Ikehata and J. A. Nicell, "Color and toxicity removal following tyrosinase-catalyzed oxidation of phenols," Biotechnology Progress, vol. 16, no. 4, pp. 533-540, 2000. 
[101] S. M. Marino, S. Fogal, M. Bisaglia et al., "Investigation of Streptomyces antibioticus tyrosinase reactivity toward chlorophenols," Archives of Biochemistry and Biophysics, vol. 505, no. 1, pp. 67-74, 2011.

[102] J. P. Jadhav, D. C. Kalyani, A. A. Telke, S. S. Phugare, and S. P. Govindwar, "Evaluation of the efficacy of a bacterial consortium for the removal of color, reduction of heavy metals, and toxicity from textile dye effluent," Bioresource Technology, vol. 101, no. 1, pp. 165-173, 2010.

[103] R. G. Saratale, G. D. Saratale, J. S. Chang, and S. P. Govindwar, "Bacterial decolorization and degradation of azo dyes: a review," Journal of the Taiwan Institute of Chemical Engineers, vol. 42, no. 1, pp. 138-157, 2011.

[104] J. V. Bevilaqua, M. C. Cammarota, D. M. G. Freire, and G. L. Santanna Jr., "Phenol removal through combined biological and enzymatic treatments," Brazilian Journal of Chemical Engineering, vol. 19, no. 2, pp. 151-158, 2002.

[105] H. Xue and Z. Shen, "A highly stable biosensor for phenols prepared by immobilizing polyphenol oxidase into polyanilinepolyacrylonitrile composite matrix," Talanta, vol. 57 , no. 2, pp. 289-295, 2002.

[106] J. Yu, S. Liu, and H. Ju, "Mediator-free phenol sensor based on titania sol-gel encapsulation matrix for immobilization of tyrosinase by a vapor deposition method," Biosensors and Bioelectronics, vol. 19, no. 5, pp. 509-514, 2003.

[107] K. Yamada, Y. Akiba, T. Shibuya, A. Kashiwada, K. Matsuda, and M. Hirata, "Water purification through bioconversion of phenol compounds by tyrosinase and chemical adsorption by chitosan beads," Biotechnology Progress, vol. 21, no. 3, pp. 823-829, 2005.

[108] G. A. Rivas and V. M. Solis, "Indirect electrochemical determination of L-tyrosine using mushroom tyrosinase in solution," Analytical Chemistry, vol. 63, no. 23, pp. 2762-2765, 1991.

[109] A. I. Yaropolov, A. N. Kharybin, J. Emnéus, G. Marko-Varga, and L. Gorton, "Flow-injection analysis of phenols at a graphite electrode modified with co-immobilised laccase and tyrosinase," Analytica Chimica Acta, vol. 308, no. 1-3, pp. 137-144, 1995.

[110] C. R. Tillyer and P. T. Gobin, “The development of a catechol enzyme electrode and its possible use for the diagnosis and monitoring of neural crest tumours," Biosensors and Bioelectronics, vol. 6, no. 7, pp. 569-573, 1991.

[111] G. Wang, J.-J. Xu, L.-H. Ye, J.-J. Zhu, and H.-Y. Chen, "Highly sensitive sensors based on the immobilization of tyrosinase in chitosan," Bioelectrochemistry, vol. 57, no. 1, pp. 33-38, 2002.

[112] J. Wang, L. Fang, and D. Lopez, "Amperometric biosensor for phenols based on a tyrosinase-graphite-epoxy biocomposite," Analyst, vol. 119, no. 3, pp. 455-458, 1994.

[113] J. Wang, F. Lu, and D. Lopez, "Tyrosinase-based ruthenium dispersed carbon paste biosensor for phenols," Biosensors and Bioelectronics, vol. 9, no. 1, pp. 9-15, 1994.

[114] P. Önnerfjord, J. Emnéus, G. Marko-Varga, and L. Gorton, "Tyrosinase graphite-epoxy based composite electrodes for detection of phenols," Biosensors and Bioelectronics, vol. 10, no. 6-7, pp. 607-619, 1995.

[115] C. Védrine, S. Fabiano, and C. Tran-Minh, "Amperometric tyrosinase based biosensor using an electrogenerated polythiophene film as an entrapment support," Talanta, vol. 59, no. 3 , pp. 535-544, 2003.

[116] R. Rajesh, W. Takashima, and K. Kaneto, "Amperometric tyrosinase based biosensor using an electropolymerized PTS-doped polypyrrole film as an entrapment support," Reactive \& Functional Polymers, vol. 59, no. 2, pp. 163-169, 2004.
[117] S. Campuzano, B. Serra, M. Pedrero, F. J. M. de Villena, and J. M. Pingarrón, "Amperometric flow-injection determination of phenolic compounds at self-assembled monolayer-based tyrosinase biosensors," Analytica Chimica Acta, vol. 494, no. 1-2, pp. 187-197, 2003.

[118] T. Tatsuma and T. Sato, "Self-wiring from tyrosinase to an electrode with redox polymers," Journal of Electroanalytical Chemistry, vol. 572, no. 1, pp. 15-19, 2004.

[119] Z. Liu, B. Liu, J. Kong, and J. Deng, "Probing trace phenols based on mediator-free alumina sol-gel-derived tyrosinase biosensor," Analytical Chemistry, vol. 72, no. 19, pp. 4707-4712, 2000.

[120] Y.-F. Li, Z.-M. Liu, Y.-L. Liu, Y.-H. Yang, G.-L. Shen, and R.-Q. $\mathrm{Yu}$, "A mediator-free phenol biosensor based on immobilizing tyrosinase to $\mathrm{ZnO}$ nanoparticles," Analytical Biochemistry, vol. 349, no. 1, pp. 33-40, 2006.

[121] S. Tembe, M. Karve, S. Inamdar, S. Haram, J. Melo, and S. F. D'Souza, "Development of electrochemical biosensor based on tyrosinase immobilized in composite biopolymeric film," Analytical Biochemistry, vol. 349, no. 1, pp. 72-77, 2006.

[122] G. B. Seetharam and B. A. Saville, "Degradation of phenol using tyrosinase immobilized on siliceous supports," Water Research, vol. 37, no. 2, pp. 436-440, 2003.

[123] S. R. Ahmed, A. T. Lutes, and T. A. Barbari, "Specific capture of target proteins by oriented antibodies bound to tyrosinaseimmobilized Protein A on a polyallylamine affinity membrane surface," Journal of Membrane Science, vol. 282, no. 1-2, pp. 311321, 2006.

[124] J. L. H. C. Busch, K. Hrncirik, E. Bulukin, C. Boucon, and M. Mascini, "Biosensor measurements of polar phenolics for the assessment of the bitterness and pungency of virgin olive oil," Journal of Agricultural and Food Chemistry, vol. 54, no. 12, pp. 4371-4377, 2006.

[125] K. Streffer, E. Vijgenboom, A. W. J. W. Tepper et al., "Determination of phenolic compounds using recombinant tyrosinase from Streptomyces antibioticus," Analytica Chimica Acta, vol. 427, no. 2, pp. 201-210, 2001.

[126] F. Ortega, E. Domínguez, E. Burestedt, J. Emnéus, L. Gorton, and G. Marko-Varga, "Phenol oxidase-based biosensors as selective detection units in column liquid chromatography for the determination of phenolic compounds," Journal of Chromatography $A$, vol. 675, no. 1-2, pp. 65-78, 1994.

[127] J.-L. Marty, K. Sode, and I. Karube, "Biosensor for detection of organophosphate and carbamate insecticides," Electroanalysis, vol. 4, no. 2, pp. 249-252, 1992.

[128] T. Shekhovtsova and S. Chernetskaya, "Determination of mercury at the picogram per milliliter level using immobilized horseradish peroxidase," Analytical Letters, vol. 27, no. 15, pp. 2883-2898, 1994.

[129] C. M. Aberg, T. Chen, A. Olumide, S. R. Raghavan, and G. F. Payne, "Enzymatic grafting of peptides from casein hydrolysate to chitosan. Potential for value-added byproducts from foodprocessing wastes," Journal of Agricultural and Food Chemistry, vol. 52, no. 4, pp. 788-793, 2004.

[130] J. Huang, C. Liu, H. Xiao, J. Wang, D. Jiang, and E. Gu, “Zinc tetraaminophthalocyanine- $\mathrm{Fe}_{3} \mathrm{O}_{4}$ nanoparticle composite for laccase immobilization," International Journal of Nanomedicine, vol. 2, no. 4, pp. 775-784, 2007.

[131] L. Tang, G. Zeng, J. Liu et al., "Catechol determination in compost bioremediation using a laccase sensor and artificial neural networks," Analytical \& Bioanalytical Chemistry, vol. 391, no. 2, pp. 679-685, 2008. 
[132] S. Wang, Y. Tan, D. Zhao, and G. Liu, "Amperometric tyrosinase biosensor based on $\mathrm{Fe}_{3} \mathrm{O}_{4}$ nanoparticles-chitosan nanocomposite," Biosensors and Bioelectronics, vol. 23, no. 12, pp. 17811787, 2008.

[133] L. M. Rossi, A. D. Quach, and Z. Rosenzweig, "Glucose oxidasemagnetite nanoparticle bioconjugate for glucose sensing," Analytical \& Bioanalytical Chemistry, vol. 380, no. 4, pp. 606-613, 2004.

[134] J. Qiu, H. Peng, and R. Liang, "Ferrocene-modified $\mathrm{Fe}_{3} \mathrm{O}_{4} @ \mathrm{SiO}_{2}$ magnetic nanoparticles as building blocks for construction of reagentless enzyme-based biosensors," Electrochemistry Communications, vol. 9, no. 11, pp. 2734-2738, 2007.

[135] S. Motamed, F. Ghaemmaghami, and I. Alemzadeh, "Turnip (Brassica rapa) peroxidase: purification and characterization," Industrial \& Engineering Chemistry Research, vol. 48, no. 23, pp. 10614-10618, 2009.

[136] S. E. Stanca, I. C. Popescuo, and L. Oniciu, "Biosensors for phenol derivatives using biochemical signal amplification," Talanta, vol. 61, no. 4, pp. 501-507, 2003.

[137] M. Kawakami, H. Koya, K. Amada, and M. Shimojo, "Amperometric 2,4-dichlorophenoxyacetate biosensor system based on a microbial reactor and a tyrosinase-modified electrode," Analytical Letters, vol. 40, no. 5, pp. 921-932, 2007.

[138] R. Rastall, Novel Enzyme Technology for Food Applications, Woodhead Publishing, Cambridge, UK, 2007.

[139] J. Buchert, E. Selinheimo, K. Kruus, M. L. Mattinen, R. Lantto, and K. Autio, "Cross-linking enzymes in food processing," in Novel Enzyme Technology for Food Applications, R. Rastall, Ed., Woodhead Publishing, Cambridge, UK, 2007.

[140] G. Freddi, A. Anghileri, S. Sampaio, J. Buchert, P. Monti, and P. Taddei, "Tyrosinase-catalyzed modification of Bombyx mori silk fibroin: grafting of chitosan under heterogeneous reaction conditions," Journal of Biotechnology, vol. 125, no. 2, pp. 281-294, 2006.

[141] B. Dunnewind, T. van Vliet, and R. Orsel, "Effect of oxidative enzymes on bulk rheological properties of wheat flour doughs," Journal of Cereal Science, vol. 36, no. 3, pp. 357-366, 2002.

[142] E. Selinheimo, Tyrosinase and laccase as novel crosslinking tools for food biopolymers [Ph.D. thesis], Helsinki University of Technology, Helsinki, Finland, 2008.

[143] E. J. Land, C. A. Ramsden, and P. A. Riley, "Quinone Chemistry and Melanogenesis," Methods in Enzymology, vol. 378, pp. 88109, 2004.

[144] H. Zhao and J. H. Waite, "Coating proteins: structure and crosslinking in fp-1 from the green shell mussel Perna canaliculus," Biochemistry, vol. 44, no. 48, pp. 15915-15923, 2005.

[145] S. Bittner, "When quinones meet amino acids: chemical, physical and biological consequences," Amino Acids, vol. 30, no. 3, pp. 205-224, 2006.

[146] S. Takasaki and S. Kawakishi, "Formation of protein-bound 3,4-dihydroxyphenylalanine and 5-S-cysteinyl-3,4-dihydroxyphenylalanine as new cross-linkers in gluten," Journal of Agricultural and Food Chemistry, vol. 45, no. 9, pp. 3472-3475, 1997.

[147] J. G. Jee, S. J. Park, and H. J. Kim, "Tyrosinase-induced crosslinking of tyrosine-containing peptides investigated by matrix-assisted laser desorption/ionization time-of-flight mass spectrometry," Rapid Communication in Mass Spectrometry, vol. 14, no. 16, pp. 1563-1567, 2000.

[148] R. M. Desentis-Mendoza, H. Hernández-Sánchez, A. Moreno et al., "Enzymatic polymerization of phenolic compounds using laccase and tyrosinase from Ustilago maydis," Biomacromolecules, vol. 7, no. 6, pp. 1845-1854, 2006.
[149] E. Matuschek and U. Svanberg, "The effect of fruit extracts with polyphenol oxidase (PPO) activity on the in vitro accessibility of iron in high-tannin sorghum," Food Chemistry, vol. 90, no. 4, pp. 765-771, 2005.

[150] M. R. Montereali, L. D. Seta, W. Vastarella, and R. Pilloton, "A disposable Laccase-Tyrosinase based biosensor for amperometric detection of phenolic compounds in must and wine," Journal of Molecular Catalysis B: Enzymatic, vol. 64, no. 3-4, pp. 189-194, 2010.

[151] J. F. Osma, J. L. Toca-Herrera, and S. Rodríguez-Couto, "Uses of laccases in the food industry," Enzyme Research, vol. 2010, Article ID 918761, 2010.

[152] G. F. Payne and W.-Q. Sun, “Tyrosinase reaction and subsequent chitosan adsorption for selective removal of a contaminant from a fermentation recycle stream," Applied and Environmental Microbiology, vol. 60, no. 2, pp. 397-401, 1994.

[153] T. Kuninori, J. Nishiyama, and H. Matsumoto, "Effect of mushroom extract upon the physical properties of dough," Cereal Chemistry, vol. 53, pp. 420-428, 1976.

[154] S. Takasaki, S. Kawakishi, M. Murata, and S. Homma, "Polymerisation of gliadin mediated by mushroom tyrosinase," LWT_Food Science and Technology, vol. 34, no. 8, pp. 507-512, 2001.

[155] S. Ito, T. Kato, K. Shinpo, and K. Fujita, "Oxidation of tyrosine residues in proteins by tyrosinase. Formation of protein-bonded 3,4-dihydroxyphenylalanine and 5-S-cysteinyl-3,4-dihydroxyphenylalanine," Biochemical Journal, vol. 222, no. 2, pp. 407-411, 1984.

[156] C. R. Thalmann and T. Lötzbeyer, "Enzymatic cross-linking of proteins with tyrosinase," European Food Research and Technology, vol. 214, no. 4, pp. 276-281, 2002.

[157] R. Lantto, P. Plathin, M. Niemistö, J. Buchert, and K. Autio, "Effects of transglutaminase, tyrosinase and freeze-dried apple pomace powder on gel forming and structure of pork meat," LWT_Food Science and Technology, vol. 39, no. 10, pp. 1117-1124, 2006.

[158] R. Lantto, E. Puolanne, K. Kruus, J. Buchert, and K. Autio, "Tyrosinase-aided protein cross-linking: effects on gel formation of chicken breast myofibrils and texture and water-holding of chicken breast meat homogenate gels," Journal of Agricultural and Food Chemistry, vol. 55, no. 4, pp. 1248-1255, 2007.

[159] R. Lantto, E. Puolanne, N. Kalkkinen, J. Buchert, and K. Autio, "Enzyme-aided modification of chicken-breast myofibril proteins: effect of laccase and transglutaminase on gelation and thermal stability," Journal of Agricultural and Food Chemistry, vol. 53, no. 23, pp. 9231-9237, 2005.

[160] R. Lantto, E. Puolanne, K. Katina, M. Niemistö, J. Buchert, and K. Autio, "Effect of laccase and transglutaminase on the textural and water-binding properties of cooked chicken breast meat gels," European Food Research and Technology, vol. 225, no. 1, pp. 75-83, 2007.

[161] G. Seetharam and B. A. Saville, "L-DOPA production from tyrosinase immobilized on zeolite," Enzyme and Microbial Technology, vol. 31, no. 6, pp. 747-753, 2002.

[162] G. M. J. Carvalho, T. L. M. Alves, and D. M. G. Freire, "L-DOPA production by immobilized tyrosinase," Applied Biochemistry and Biotechnology, vol. 84-86, no. 1-9, pp. 791-800, 2000.

[163] R. Lantto, E. Heine, G. Freddi et al., "Enzymatic modification of wool with tyrosinase and peroxidase," The Journal of The Textile Institute, vol. 96, no. 2, pp. 109-116, 2005.

[164] M.-L. Mattinen, R. Lantto, E. Selinheimo, K. Kruus, and J. Buchert, "Oxidation of peptides and proteins by Trichoderma 
reesei and Agaricus bisporus tyrosinases," Journal of Biotechnology, vol. 133, no. 3, pp. 395-402, 2008.

[165] "Burn Dressigns," in BioMaterials Science: An Introduction to Materials in Medicine, J. B. Kane, R. G. Tompkins, M. L. Yarmush et al., Eds., pp. 360-370, Academic Press, San Diego, Calif, USA, 1996.

[166] K. Y. Lee and D. J. Mooney, "Hydrogels for tissue engineering," Chemical Reviews, vol. 101, no. 7, pp. 1869-1879, 2001.

[167] M. E. Marín-Zamora, F. Rojas-Melgarejo, F. García-Cánovas, and P. A. García-Ruiz, "Production of $o$-diphenols by immobilized mushroom tyrosinase," Journal of Biotechnology, vol. 139, no. 2, pp. 163-168, 2009.

[168] M. Guazzaroni, C. Crestini, and R. Saladino, "Layer-by-Layer coated tyrosinase: an efficient and selective synthesis of catechols," Bioorganic \& Medicinal Chemistry, vol. 20, no. 1, pp. 157166, 2012.

[169] T. Bozzini, G. Botta, M. Delfino et al., "Tyrosinase and Layerby-Layer supported tyrosinases in the synthesis of lipophilic catechols with antiinfluenza activity," Bioorganic \& Medicinal Chemistry, vol. 21, no. 24, pp. 7699-7708, 2013. 

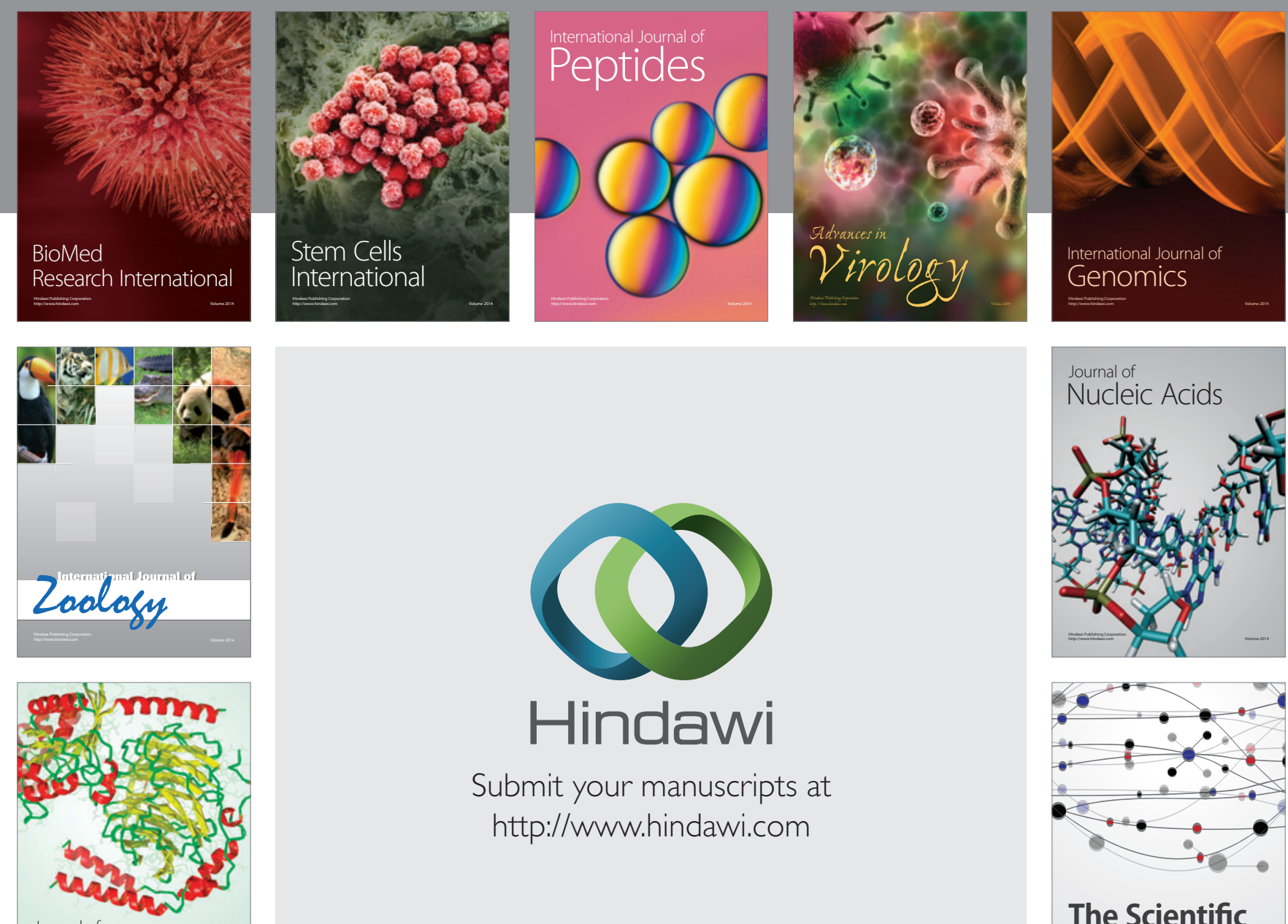

Submit your manuscripts at

http://www.hindawi.com

Journal of
Signal Transduction
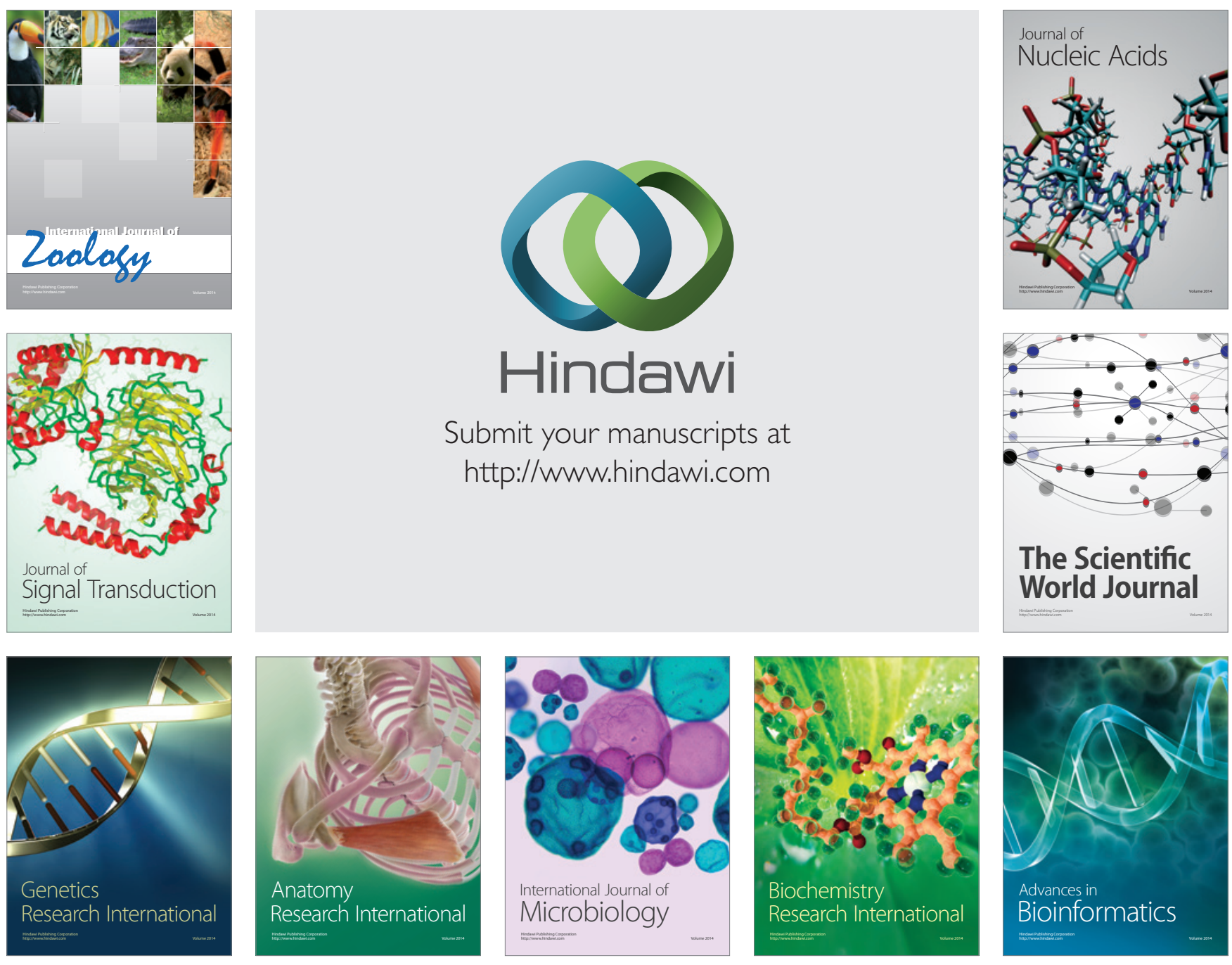

The Scientific World Journal
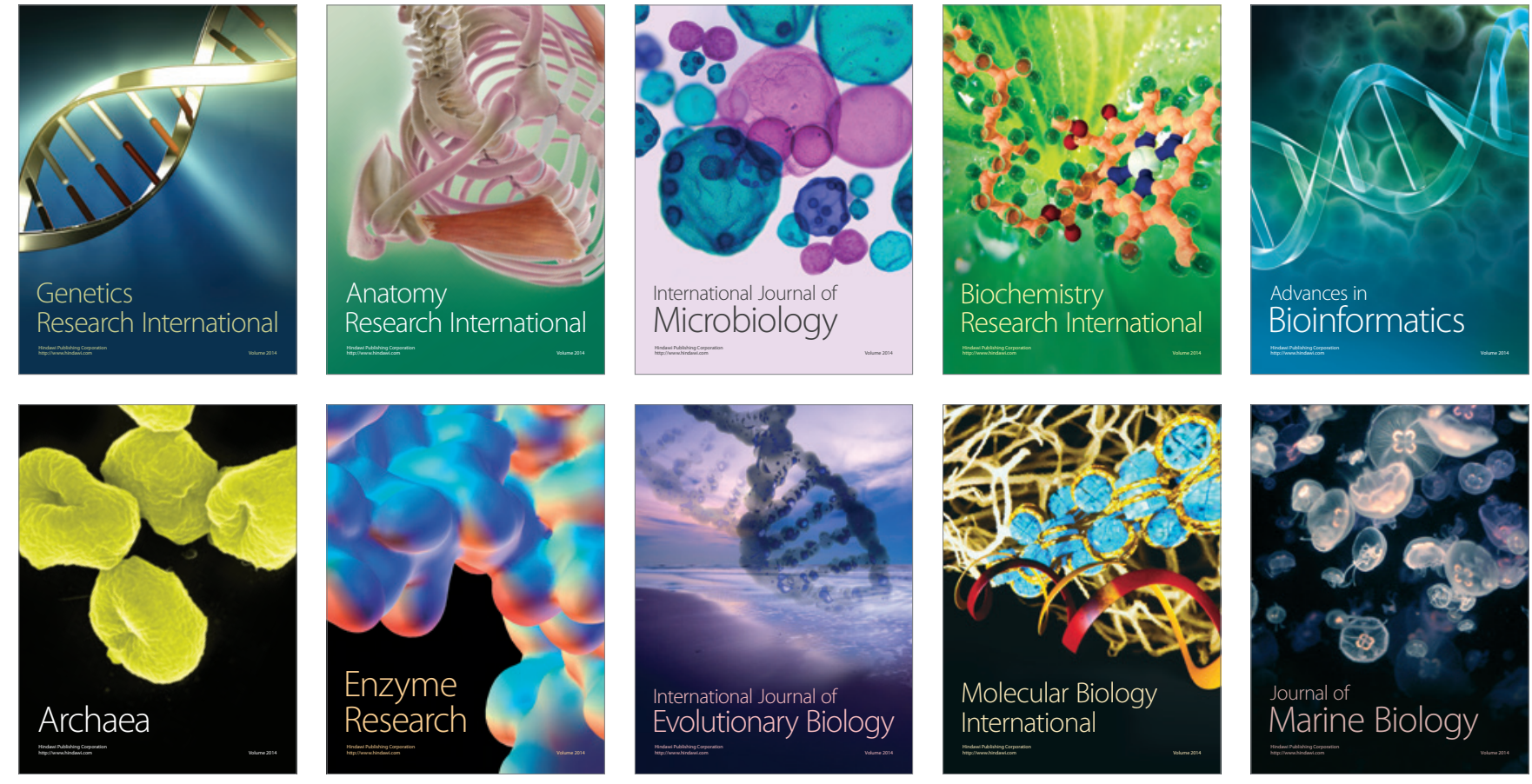